\title{
Respect for the Doctor (Sir 38:1-3)
}

\author{
ANDRZEJ PIWOWAR \\ Institute of Biblical Studies, John Paul II Catholic University of Lublin \\ andpiw@gazeta.pl \\ ORCID: 0000-0001-9316-1791
}

\begin{abstract}
Aвstract: The first part of the article synthetically presents the attitudes of the Old Testament Israelites to doctors and their work. It is an essential prerequisite for the depiction of the innovative approach to the issue proposed by Ben Sira in Sir 38:1-3. The article is devoted to the exegetico-theological analysis of Sir 38:1-3. Even though the article is based primarily on the Greek text of the pericope, it takes into account its original Hebrew version as well. Ben Sira calls on the believing Israelites to completely change their perception of doctors and their activities. He encourages his readers not to reject doctors but to treat them with respect and reverence, and, indirectly, not to ignore the doctor's efforts meant to restore health to the sick one. The sage justifies his novel approach with two arguments. First, doctors were created by God and given the task of aiding the sick in their suffering. They are a mere tool in God's hands, for God is the only Doctor that can truly heal a person (this aspect is emphasized more by the Hebrew text than by its Greek counterpart). Secondly, doctors deserve respect for even kings and dignitaries benefit from their services and treat them with respect and reverence. In 38:1-3 Ben Sira offers a perfect synthesis of Israel's traditional belief in God, who is the only doctor able to heal a person, with the Hellenistic influence related to medicine and people who engage in it.
\end{abstract}

KEYWORDs: the Wisdom of Sirach; Sir 38:1-3; doctor

$\mathrm{T}$ he Bible is a book that speaks primarily of God's revealing himself to the people and of mutual relations between these two subjects. This is the major theme of biblical books. It would be a mistake, however, to claim that the Bible is limited to this content only. It is a major subject that all the others are subordinate to, but the Holy Scripture contains numerous and valuable details about the people described and various aspects of their lives. One example could be professions performed in biblical times. The books of the Bible obviously do not give exhaustive answers to all the questions related to the sphere of productive activity (e.g. the methods of producing certain goods); still the reader may find a lot of important information on the issue. One of the professions mentioned in the Bible is that of a doctor. It is the doctors and their work that the present article will focus on, analyzing the text of Sir 38:1-3, a pericope that is unique in the whole Bible with respect to the profession in question. First, the article will synthetically present the way in which doctors' work is presented in the Old Testament and the Israelites' approach to it. Subsequently, 
the Greek text of Sir 38:1-3 will be analyzed, a text that directly addresses the figure of a doctor.

\section{A Doctor and His Work in the Old Testament}

The biblical view on the doctor and his work aimed at restoring health to the sick one is based on the Israelites' religious convictions in ancient times. ${ }^{1}$ It is worth mentioning that their perception of the issue was similar to that of other nations of the ancient Middle East. ${ }^{2}$ Illness was generally perceived as a consequence of sin and punishment for evil deeds (cf. Num 12:11-12; Deut 28:15-69; Ps 38:4). ${ }^{3}$ Such a perspective was still visible in the times of Jesus (see Jn 9:2: "Rabbi, who sinned, this man or his parents, that he was born blind?"). Physical suffering and pain were then not only of somatic/psychic character, but they

1 See J. Giblet - P. Grelot, "Choroba-uleczenie," Stownik teologii biblijnej (ed. X. Leon-Dufour) (Poznań: Pallottinum 1990) 121-122; G. Ravasi, "Malattia, Guarigione e medici nell'Antico Testamento," PSV 40 (1999) 11-13.

2 See L.A. Askin, Scribal Culture in Ben Sira (Sir 38:1-15; 41:1-15; 43:11-19; 44-50) (unpublished doctoral dissertation defended in 2016 in Queen's College, Cambridge University) 212.220; Giblet - Grelot, "Choroba-uleczenie," 121; F. Graber - D. Müller, "ióopal," New International Dictionary of the New Testament Theology (ed. C. Brown) (Carlise - Grand Rapids, MI: Paternoster Press

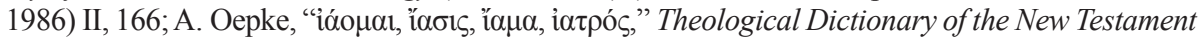
(ed. G. Kittel) (Grand Rapids, MI: Eerdmans 1995) III, 195; D.P. Sulmasy, "The Covenant within the Covenant: Doctors and Patients in Sir 38:1-15," LQ 55 (1988) 17.

3 See M. Adinolfi, "Il medico in Sir 38,1-15," Antonianum 62 (1987) 180; N. Allan, "The Physician in Ancient Israel: His Status and Function," Medical History 45 (2001) 377; J.L. Crenshaw, "The Book of Sirach. Introduction, Commentary, and Reflection,” The New Interpreter's Bible (ed. L.E. Keck) (Nashville, TN: Abingdon Press 1997) V, 807; S. Fasce, La lode del medico nel libro biblico del Siracide (Genova: ECIG 2009) 34; Giblet - Grelot, "Choroba-uleczenie," 122-123; L. Mazzinghi, "«Poi fa' posto al Medico, perché ti è necessario» (Sir 38,1-15)," PSV 40 (1999) 68; Ravasi, "Malattia, Guarigione e medici nell'Antico Testamento," 13-14; L. Rykel - J.C. Wilhoit - T. Longman III (ed.), Le immagini bibliche. Simboli, figure retoriche e temi letterari della Bibbia (Dizionari San Paolo; Cinisello Balsamo: San Paolo 2006) 831-832; J.G. Snaith, Ecclesiasticus or The Wisdom of Jesus Son of Sirach (The Cambridge Bible Commentary; Cambridge: Cambridge University Press 1974) 184; W.M. Stabryła, "Zdrowie i choroba w starożytnym Izraelu," Więcej szczęścia jest w dawaniu aniżeli w braniu. Księga Pamiatkowa dla Księdza Profesora Waldemara Chrostowskiego w 60. rocznice urodzin (ed. B. Strzałkowska) (Ad Multos Annos; Warszawa: Adam 2011) III, 1317-1318, 1323; A. Stöger, "Der Arzt nach Jesus Sirach (38,1-15)," ArztChr 1/11 (1965) 9; Sulmasy, "The Covenant within the Covenant," 19-20; E. Testa, "Le malattie e il medico secodno la Bibbia," RivB 43 (1995) 256-257, 262-263; M. Zakrzewska, "Choroba - zło dotykające człowieka," Biblia a medycyna (ed. B. Pawlaczyk) (Poznań: Księgarnia Świętego Wojciecha 2007) 17, 22-23; B.M. Zapff, Jesus Sirach 25 - 51 (Die Neue Echter Bibel. Altes Testament; Würzburg: Echter 2010) 253. M. Münnich lists the following among the causes of illness: infidelity to the Covenant and the Law, idolatry, disobedience to Yahweh and his messengers, cult offences, sexual transgressions, murder, social misdemeanors, census, sin, rebellion, etc. (see M. Münnich, Obraz Jahwe jako wtadcy choroby w Biblii hebrajskiej na tle bóstw bliskowschodnich [Lublin: Wydawnictwo KUL 2004] 233-305). 
pertained to religion and faith in God. If an illness was a result of depravity, its treatment likewise had a religious dimension and was strictly related to a man's relationship with God. On account of this, the Old Testament Jews before the Babylonian captivity (6th century BCE) believed that God was the only doctor (cf. Ex 15:264; Deut 32:39; 2 Kings 20:5,8; Job 5:18; Ps 103:3; 107:20; 147:1-3; Is $19: 22 ; 57: 18-19 ; 61: 1$; Jer $30: 17 ; 33: 6$ and Hos $6: 1 ; 11: 3) .{ }^{5}$ Only God could heal a person and free him or her from maladies. ${ }^{6}$ Questioning this truth was deemed a violation of the purity of faith. ${ }^{7}$ As a result of these convictions, the Jews treated doctors with a great deal of reservation, which found its reflection in a rejection of the doctors' activity $^{8}$ (this is disproved, however, by Gaiser ${ }^{9}$ and Askin $^{10}$ ). This attitude stemmed also from the fact that erstwhile doctors re-

4 "Many scholars point to Exod 15:26 as an explanation for the biblical silence on physicians and medical treatment" (I. Cranz, "Advice for a Successful Doctor's Visit: King Asa Meets Ben Sira," CBQ 80 [2018] 233). Cf. M.L. Brown, "רָָָ rāpa ',", Theological Dictionary of the Old Testament (ed. G.J. Botterweck - H. Ringgren - H.-J. Fabry) (Grand Rapids, MI - Cambridge: Eerdmans 2004) XIII, 601; F. Gaiser, “"The Sensible Will Not Despise Him': Healing Medicine, Human Wisdom and God (Sirach 38:1-15)," Healing in the Bible: Theological Insight for Christian Ministry (ed. F.J. Gaiser) (Grand Rapids, MI: Baker 2010) 118; B.M. Zapff, "Sir 38,1-15 als Beispiel der Verknüpfung von Tradition und Innovation bei Jesus Sirach," Biblica 92 (2011) 349.

5 See Adinolfi, "Il medico in Sir 38,1-15," 176; Askin, Scribal Culture in Ben Sira, 213; Crenshaw, "The Book of Sirach," 807; Fasce, La lode del medico, 31; Gaiser, "The Sensible Will Not Despise Him,"” 122; Giblet - Grelot, "Choroba-uleczenie," 123; Graber - Müller, "ióoual," 167; H.C. Kee, "Medicine and Healing," The Anchor Bible Dictionary (ed. D.N. Freedman) (New York - London - Toronto: Doubleday 1992) IV, 659-660; D. Lührmann, "Aber auch Arzt gib Raum (Sir 38,1-15)," WD 15 (1979) 56-57; Mazzinghi, “«Poi fa' posto al Medico, perché ti è necessa-

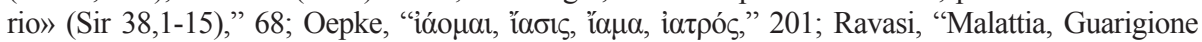
e medici nell'Antico Testamento," 17-18, 20; W.M. Stabryła, “"Najlepszego nawet lekarza czeka Gehenna'. Lekarz w starożytnym Izraelu," AK 1 (2013) 8; idem, "Zdrowie i choroba w starożytnym Izraelu," 1323-1324; Stöger, "Der Arzt nach Jesus Sirach (38,1-15)," 5; Sulmasy, "The Covenant within the Covenant," 16; Testa, "Le malattie e il medico secodno la Bibbia," 253-254.256.258-260; H.W. Wolff, Antropologia dell'Antico Testamento, 4th ed. (Biblioteca Biblica 12; Brescia: Queriniana 2002) 191; Zakrzewska, "Choroba - zło dotykające człowieka," 23-24; Zapff, Jesus Sirach 25 - 51, 253. Chrostowski ("Lekarz i jego posługa w świetle Biblii," CT 3 [2001] 51-54) posits that the second description of the creation of the world (Gen 2:4b-3:24) presents God as a doctor of four specializations: anesthetist, orthopedist, surgeon and plastic surgeon. In his view, God is depicted in the same role during the Israelites' journey through the desert at the time of the exodus from Egypt (Ex 15:22-27).

6 See Münnich, Obraz Jahwe jako władcy choroby, 45-116; Stabryła, "Zdrowie i choroba w starożytnym Izraelu," 1324.

7 See Allan, "The Physician in Ancient Israel," 379, 393; G. Pérez Rodríguez, "Eclesiástico," Biblia Comentada. IV. Libros Sapienciales, 2nd ed. (Biblioteca de Autores Cristianos 218; Madrid: Editorial Católica 1967) 1242; Stabryła, "“Najlepszego nawet lekarza czeka Gehenna,"” 8; idem, "Zdrowie i choroba w starożytnym Izraelu," 1323-1324.

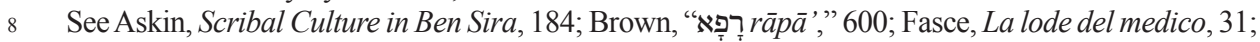
Mazzinghi, "«Poi fa' posto al Medico, perché ti è necessario» (Sir 38,1-15)," 68; Stabryła, "Zdrowie i choroba w starożytnym Izraelu," 1317; Sulmasy, "The Covenant within the Covenant," 16.

$9 \quad$ See Gaiser, “"The Sensible Will Not Despise Him," 121-122.

10 See Askin, Scribal Culture in Ben Sira, 212-214, 218-219. 
sorted to magic, ${ }^{11}$ which was clearly condemned and forbidden by the Law (see Ex 22:17; Lev 20:6,27; Deut 18:9-14; Is 47:9; Jer 27:9). ${ }^{12}$ Magical practices were part and parcel of doctors' activity: doctors resorted to magic both in treating their patients and in preparing medicaments. ${ }^{13}$ This is corroborated by numerous testimonies and sources, both Egyptian and Mesopotamian. This does not mean, however, that medicine was restricted to magic only. Doctors working in Egypt knew fairly well the constitution of the human body thanks to the practice of corpse embalming. Their knowledge even allowed them to conduct surgeries. They did not know much about the causes of the vast majority of diseases, however, as they were not knowledgeable about the physiology of the human body. ${ }^{14}$ Ravasi gives yet another reason for the negative attitude of the Israelites to physicians and their work in the early stage of Israel's development. He maintains that such an approach stemmed from the Law itself, as it forbade contact with blood or a dead body (cf. Num 19:10-22). These restrictions contributed to an absence of medicinal progress among the Israelites and to the perception of doctors as impure people, contact with whom was prohibited. ${ }^{15}$

The books of the Old Testament make use of the word רפָא (participium Qal of the root רפא - "to heal"16) only five times with reference to a person professionally healing others ${ }^{17}$ (Wolff ${ }^{18}$ and Zapff ${ }^{19}$ posit that doctors in the Bible only cured wounds). In Gen 50:2 the term appears twice in the plural form (הָרפְִִִים). It does not refer to doctors as such, that is to people treating patients, but to Egyptian priests engaged in embalming corpses. $.^{20} 2 \mathrm{Chrn} 16: 12$ mentions the suffering of King Asa on account of leg disease. He did not seek cure in God, however, but

11 See Askin, Scribal Culture in Ben Sira, 184; Giblet - Grelot, "Choroba-uleczenie," 121; Lührmann, "Aber auch Arzt gib Raum (Sir 38,1-15)," 55; Stabryła, "Najlepszego nawet lekarza czeka Gehenna," 8; idem, "Zdrowie i choroba w starożytnym Izraelu," 1327, 1333; Sulmasy, "The Covenant within the Covenant," 16; J. Turkiel, "Septuaginta o lekarzu," Nauki humanistyczne i sozologia. Księga jubileuszowa dedykowana Księdzu Profesorowi zwyczajnemu doktorowi habilitowanemu Józefowi M. Dotędze (ed. J.W. Czartoszewski) (Warszawa: Wydawnictwo UKSW 2010) 563-564; Zapff, "Sir 38,1-15 als Beispiel," 349-350.

12 See Allan, "The Physician in Ancient Israel," 378, 379; Stabryła, "Zdrowie i choroba w starożytnym Izraelu," 1317.

13 See Zakrzewska, "Choroba - zło dotykające człowieka," 18.

14 See Askin, Scribal Culture in Ben Sira, 219; Stabryła, "Najlepszego nawet lekarza czeka Gehenna," 8.

15 See Ravasi, "Malattia, Guarigione e medici nell'Antico Testamento," 20-21. Cf. Wolff, Antropologia dell'Antico Testamento, 190, footnote 17.

16 See Allan, "The Physician in Ancient Israel," 380; Chrostowski, "Lekarz i jego posługa w świetle Biblii," 57.

17 See Kee, "Medicine and Healing," 660.

18 See Wolff, Antropologia dell'Antico Testamento, 188.

19 See Zapff, "Sir 38,1-15 als Beispiel," 349.

20 In Gen 50:2 the root רפא is used in its original meaning of "sewing" (see Brown, "רפָָז rāpā"," 594-597; Wolff, Antropologia dell'Antico Testamento, 188). Cf. Adinolfi, "Il medico in Sir 38,1-15," 176; Allan, "The Physician in Ancient Israel," 380; Brown, "רָָָ rāpā',", 600; Ravasi, "Malattia, Guari- 


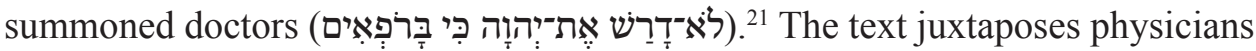
and JHWH and corroborates a univocally negative assessment of their activity, perceived as a sign of lack of trust and faith in the Divine Doctor (a parallel text, that is 1 Kings 15:23-24, does not mention doctors at all). ${ }^{22}$ Cranz emphasizes the fact that the chronicler might have assessed the attitude of the ruler so negatively as a result of the fact that instead of the word רפִִּים ("doctors") he may have read רְפִִָָים ("the dead," "spirits of the dead"; see Is 26:19; Job 26:5). The chronicler would have expressed in this way acute criticism of necromancy. ${ }^{23}$ Brown stresses the irony inherent in Asa's attitude, for the king's name may have signified "God/Yahweh (is) my doctor." friends, whose words have no value. ${ }^{25}$ The noun is used here metaphorically and not literally. In Jer 8:22 it is used, in turn, to emphasize the tragedy of the nation that will not be delivered. ${ }^{26}$ Jeremiah's words, however, confirm the presence of doctors and the use of medicaments in pre-exile Israel. ${ }^{27}$

Apart from the places of the Hebrew Bible mentioned above (except for

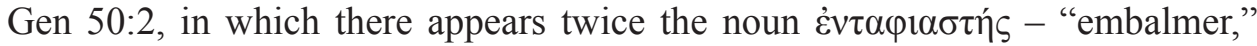
"somebody who prepares the dead body for the funeral" ${ }^{28}$ ), in the Greek trans-

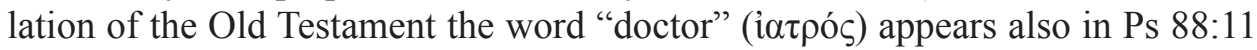
("Surely, you shall not work wonders for the dead? Or will physicians raise up, and they acknowledge you?"29). The psalm describes a man who has been seriously ill since his youth and who trusts in God despite approaching death. The verse contains two rhetorical questions, the answers to which are negative (these questions are introduced with the interrogative particle $\mu \eta$ - "does not?,"

gione e medici nell'Antico Testamento," 20; Stabryła, "Zdrowie i choroba w starożytnym Izraelu," 1324, footnote 44; Sulmasy, "The Covenant within the Covenant," 16.

21 According to Allan ("The Physician in Ancient Israel," 381), 2 Chrn 16:12 is the only text in the whole Hebrew Old Testament that univocally and unquestionably speaks of a doctor/doctors.

22 See Adinolfi, "Il medico in Sir 38,1-15," 176; Allan, "The Physician in Ancient Israel," 381; Askin, Scribal Culture in Ben Sira, 213; Brown, "רפָּא rāpā'," 600; Cranz, "Advice for a Successful Doctor's Visit," 232, 236-237; Crenshaw, "The Book of Sirach," 807; H. Duesberg, "Le médecin, un sage," BVC 38 (1961) 46; Gaiser, “"The Sensible Will Not Despise Him," 122; Stabryła, "Najlepszego nawet lekarza czeka Gehenna," " 8-9; idem, "Zdrowie i choroba w starożytnym Izraelu," 1324-1325; Stöger, "Der Arzt nach Jesus Sirach (38,1-15)," 6; Turkiel, "Septuaginta o lekarzu," 563-564; Zapff, Jesus Sirach 25 - 51, 253; idem, "Sir 38,1-15 als Beispiel," 350.

23 See Cranz, "Advice for a Successful Doctor's Visit," 232, 235-236.

24 See Brown, "רָָָָ rāpā'," 600; Cranz, "Advice for a Successful Doctor's Visit," 235.

25 See Adinolfi, "Il medico in Sir 38,1-15," 176; Allan, "The Physician in Ancient Israel," 381; Turkiel, "Septuaginta o lekarzu," 567.

26 See Adinolfi, "Il medico in Sir 38,1-15," 176; Allan, "The Physician in Ancient Israel," 381; Stabryła, "Zdrowie i choroba w starożytnym Izraelu," 1324, footnote 44; Turkiel, "Septuaginta o lekarzu," 569.

27 See Brown, "רָָָ rāpā'," 600; Cranz, "Advice for a Successful Doctor's Visit," 234.

28 See T. Muraoka, A Greek-English Lexicon of the Septuagint (Louvain - Paris - Walpole, MA: Peeters 2009) 240

29 See Stöger, "Der Arzt nach Jesus Sirach (38,1-15)," 6. 
“does?"). ${ }^{30}$ Rhetorical questions are very strong statements rather than genuine questions, as the answer they suggest is obvious and known to everyone. God does not do miracles for the dead and the doctors will not praise him. Doctors are presented here as people who do not partake of God's healing power, and

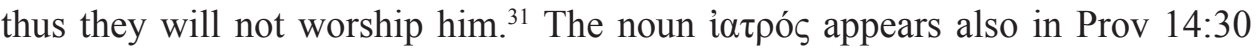
("A meek-spirited man is a healer of hearts, and a sensitive heart a moth in the bones). The word "doctor" is used here figuratively to denote those that can calm others down and restore their emotional balance. ${ }^{32}$ 'I $\alpha \tau$ có $\varsigma$ appears one more time in the Greek text of Is 26:14, which depicts the tragic fate of doctors ${ }^{33}$ ("But the dead will not see life, nor will physicians raise them up; because of this you have brought them and destroyed them and taken away all their males").

The attitude to doctors and medicine evolved with the influence of the Hellenistic culture on Israel's society. God remained the only person that could heal a sick one, but the help of physicians was not rejected in the process of regaining health, as it was the case earlier. ${ }^{34}$ A new approach to doctors and their role in healing patients was in all likelihood caused by a different (and new) conception of medicine in the Hellenistic world. It did not resort to magic to the extent it had in its earlier stage of development in the East; it was rather based on rational and empirical foundations (medicines and mixtures were prepared from plants and natural substances). ${ }^{35}$ As a result of the decrease of the role of magic in the treatment, a pious Israelite could seek doctors' help, ${ }^{36}$ but he needed to remember that only God could restore his health, while doctors were merely God's helpers and representatives.

The new approach to healing and the role of doctors in the process is best visible in the Book of Tobias. It describes a very pious person (see Tob 1; especially 1:12), who almost lost his sight as a result of an unfortunate turn of events. When he reached out to doctors, the treatment prescribed by them did not only fail to help him but caused his complete blindness (see Tob 2:9-10). Tobit's

30 See A. Piwowar, Sktadnia języka greckiego Nowego Testamentu, 2nd ed. (Materiały Pomocnicze do Wykładów z Biblistyki 13; Lublin: Wydawnictwo KUL 2017) § 460a.

31 Turkiel ("Septuaginta o lekarzu," 566) misinterpeted the text, failing to notice that Ps 88:11 has the form of rhetorical questions.

32 See Turkiel, "Septuaginta o lekarzu," 566.

33 See Turkiel, "Septuaginta o lekarzu," 569.

34 See Kee, "Medicine and Healing," 659; Stabryła, "Najlepszego nawet lekarza czeka Gehenna,"” 9.

35 See Graber - Müller, "ióo $\mu \alpha 1$, , 166; Fasce, La lode del medico, 37-38, 62-65; Kee, "Medicine and Healing," 661-662; Mazzinghi, “«Poi fa' posto al Medico, perché ti è necessario» (Sir 38,1-15)," 68; G. Sauer, Jesus Sirach/Ben Sira (Das Alte Testament Deutsch. Apokryphen 1; Göttingen: Van-

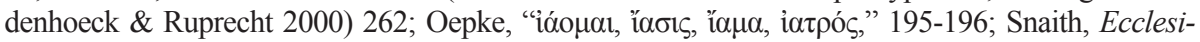
asticus, 184; Stöger, "Der Arzt nach Jesus Sirach (38,1-15)," 5; Sulmasy, "The Covenant within the Covenant," 17-18; Zakrzewska, "Choroba - zło dotykające człowieka," 19; Zapff, Jesus Sirach 25-51, 253; idem, "Sir 38,1-15 als Beispiel," 350-351.

36 See Askin, Scribal Culture in Ben Sira, 185; Stöger, "Der Arzt nach Jesus Sirach (38,1-15)," 5. 
conduct was not condemned, however, as was the case with King Asa. Unlike the ruler of Judah, Tobit was not a deeply religious person and his attitude was not an expression of lack of faith in or rebellion against God (King Hezekiah behaved in a similar way during his illness; see Is 38:1-20). ${ }^{37}$ The Lord sent to Tobit Angel Raphael (רָָָָָאל literally means "God healed"), who in the name of God healed both him and his daughter-in-law Sarah (see Tob 12:14). ${ }^{38}$ God's messenger acted in the same way as doctors: he indicated the way in which to prepare a healing mixture and how to apply it (see Tob 6:4,7-9). ${ }^{39}$ Tobit's story confirms the conviction espoused in Israel's tradition that God is the only doctor and that only he can restore health to a human being.

It needs to be emphasized that even the new approach to doctors and treatment in Hellenistic times did not completely eliminate mistrust towards them and their activities. The caution stemmed from the fact that they resorted to magic in their work..$^{40}$ The apocryphal literature of the intertestamental period testifies to the conviction that medical knowledge originates from fallen angels. ${ }^{41}$ The attitude of great caution towards doctors was not overcome even in the second century CE. ${ }^{42}$ Despite this lack of trust in doctors and their knowledge, Talmud did not univocally reject the usage of medical practice, justifying it on the basis of Exod 21:19.43

Summing up the attitude of believing Jews in the times of the Old Testament to doctors and their work, it can be claimed, following Giblet and Grelot, that the Old Testament did not forbid seeking medical help, it only condemned doctor's deployment of magic, with which their activity was frequently associated. ${ }^{44}$

37 See Allan, "The Physician in Ancient Israel," 382-383; Stabryła, "Zdrowie i choroba w starożytnym Izraelu," 1325; Turkiel, "Septuaginta o lekarzu," 565.

38 See Stabryła, "Najlepszego nawet lekarza czeka Gehenna,"” 9; Turkiel, "Septuaginta o lekarzu," 564-565.

39 Stabryła, “Najlepszego nawet lekarza czeka Gehenna," 9. Cf. Allan, "The Physician in Ancient Israel," 384; Stabryła, "Zdrowie i choroba w starożytnym Izraelu," 1325.

40 See Allan, "The Physician in Ancient Israel," 385-387; Askin, Scribal Culture in Ben Sira, 221-222. "Even advances in anatomy and causes of illness (mostly diet) never disconnected professional Classical Greek medicine from religion [...] Medicine and worship complemented each other" (Askin, Scribal Culture in Ben Sira, 221). "Trotz [...] empirisch geprägten Rationalismus des hellenistischen Ärztewesens verblieb dennoch eine religiöse Rückbindung” (Zapff, "Sir 38,1-15 als Beispiel,” 351).

41 See H. Drawnel, The Aramaic Astronomical Book (4Q208-4Q211) from Qumran. Text, Translation, and Commentary (Oxford: Oxford Press 2010) 63-70.

42 "[...] to właśnie wtedy autor traktatu Kidduszin, dając wyraz wciąż obecnym wątpliwościom odnośnie do fachu medyków, niemalże złowieszczo woła, iż 'Najlepszego nawet lekarza czeka Gehenna" (Stabryła, “"Najlepszego nawet lekarza czeka Gehenna," 11). Cf. Crenshaw, "The Book of Sirach," 808; Graber - Müller, "ióo $\mu \alpha 1$, , 168; Stabryła, "Zdrowie i choroba w starożytnym Izraelu," 1326-1327; Snaith, Ecclesiasticus, 184.

43 See Allan, "The Physician in Ancient Israel," 379-380. Cf. Sulmasy, "The Covenant within the Covenant," $18-19$.

44 Giblet - Grelot, "Choroba-uleczenie," 123. Cf. Brown, "“רָ rāpā'," 600; Kee, "Medicine and Healing," 664. 
The religious/cultural context sketched above as regards doctors and their medical practices functions as a background for Sir 38:1-3. It enables one to discern and fully understand the advice of the Jerusalem sage concerning doctors and medical treatment. Without this context it would be difficult to grasp the significance of Ben Sira's admonitions and teachings included in the pericope under study here.

\section{Direct Context and Delimitation of Sir 38:1-3}

The context directly preceding the pericope of Sir 38:1-3 constitutes the sage's admonition to his disciples to take care of themselves and steer clear of what is bad for them and what may cause problems in their lives (Sir 37:27-31). After initial advice of a general character (37:27-28), Ben Sira goes on to give more details and encourages those wishing to acquire wisdom to exercise restraint in eating, for failure to do so may lead to a disease (stomach problems) ${ }^{45}$ as a result of which many people have died (37:29-31). ${ }^{46}$ In light of such a grave threat to one's health, or even danger of death, the sage calls on his listeners not to ignore doctors (Sir 38:1-3), since their advice and help may restore health and in extreme cases even safe life. ${ }^{47}$

In the context succeeding Sir 38:1-3 the author focuses first on the origin of medicaments and medical knowledge (Sir 38:4-8), and then on the process of healing (Sir 38:9-15). In this way the pericope under analysis here constitutes a transition from a detailed section (on stomach problems) to a more general one (on doctors and medical knowledge). Since both doctors and their knowledge come from God, they are not to be ignored.

The pericope directly preceding Sir 38:1-3 begins with the expression $\tau \dot{\varepsilon} \kappa v o v$ ("child"; see Sir 38:27). The sage frequently addresses his disciples with the use of this formula, wishing to emphasize in this way the solemnity and significance of the teachings he passes on to them. ${ }^{48}$ This expression may also signal the be-

45 See J. Corley, Sirach (New Collegeville Bible Commentary 21; Collegeville, PA: Liturgical Press 2013) 103; Cranz, "Advice for a Successful Doctor's Visit," 240; N. Peters, Das Buch Jesus Sirach oder Ecclesiasticus (Exegetisches Handbuch zum Alten Testament 25; Münster: Aschendorff 1913) 311.

46 See Fasce, La lode del medico, 19-22; Mazzinghi, “«Poi fa' posto al Medico, perché ti è necessario» (Sir 38,1-15)," 67.

47 See Adinolfi, "Il medico in Sir 38,1-15," 179; M.C. Palmisano, Siracide. Introduzione, traduzione e commento (Nuova Versione della Bibbia dai Testi Antichi 34; Cinisello Balsamo: San Paolo 2016) 342; Pérez Rodríguez, "Eclesiástico," 1242; Zapff, Jesus Sirach 25 - 51, 253.

48 See A. Piwowar, "Wierność w czasie próby (Syr 2,1-6)," VV 11 (2007) 101. 
ginning of a new segment (literary unit) in Ben Sira's teaching ${ }^{49}$ or an element of the pericope's structure. ${ }^{50}$ The pericope that precedes Sir 38:1-3 and starts with $\tau \varepsilon \dot{\varepsilon} v 0 v$ ends with 37:31. This is confirmed by the deployment of the noun $\zeta \omega \eta$ ("life"), which functions as a frame for the literary unit of 37:27-31. It appears in 37:27a and in 37:31b, forming a frame for the pericope. In 38:1a the noun i $\alpha \tau$ ós ("doctor") appears, introducing a new subject matter in Ben Sira's reflections, that is the figure of a doctor. The word reappears in Sir 38:3a, forming the frame for the pericope studied in this article. In 38:4 there is a change of the protagonist of the sage's ruminations. It is no longer a doctor but God, who created medicines and endowed people with knowledge about them (Sir 38:4-8). On the basis of the arguments presented above, both formal (framing) and related to content, Sir 38:1-3 needs to be treated as a separate, coherent literary unit in Ben Sira's work ${ }^{51}$ which perfectly fits his reflections on healing and the role played by doctors therein.

\section{Translation of the Greek Version of Sir 38:1-3}

The analysis of Sir 38:1-3 in this article will be based on the Greek text of the pericope, on account of the fact that the translation of Ben Sira's work conducted by his grandson was treated as the canonical text of the book. The exegetical analysis will also compare the Greek version of Sir 38:1-3 with its Hebrew predecessor. $^{52}$

49 See Sir 2:1; 3:17; 4:1; 6:18; 16:24; 18:15; 21:1; 37:27; 38:16; 40:28. Cf. A. Minissale, Siracide. Le radici nella tradizione (Leggere Oggi la Bibbia 1.17; Brescia: Queriniana 1988) 17.

$50 \quad$ See Sir 3:12; 6:23,32; 10:28; 14:11; 31:22; 38:9. Cf. A. Piwowar, "Zdobycie mądrości według Syracha (Syr 6,18-37). Część I: Przyjęcie wychowania prowadzi do osiągnięcia mądrości (Syr 6,18-22)," BibAn 1 (2015) 113-114, 118; L. Schrader, "Beruf, Arbeit und Muße als Sinnerfüllung bei Jesus Sirach," Der Einzelne und seine Gemeinschaft bei Ben Sira (ed. R. Egger-Wenzel - I. Krammer) (BZAW 270; Berlin - New York: de Gruyter 1998) 134.

51 See Askin, Scribal Culture in Ben Sira, 207-208; Chrostowski, "Lekarz i jego posługa w świetle Biblii," 64-66; Fasce, La lode del medico, 26, 43, 77; Stöger, "Der Arzt nach Jesus Sirach (38,1-15)," 4-9.

52 See P.C. Beentjes, The Book of Ben Sira in Hebrew. A Text Edition of all Extant Hebrew Manuscripts and a Synopsis of all Parallel Hebrew Ben Sira Texts (Supplements to Vetus Testamentum 68; Leiden - New York - Köln: Brill, 1997) 65; P. Boccaccio - G. Bernardi, Ecclesiasticus. Textus hebraeus secundum fragmenta reperta (Roma: PIB 1986) 24-25; The Book of Ben Sira. Text, Concordance and an Analysis of the Vocabulary (The Historical Dictionary of the Hebrew Language; Jerusalem: The Academy of the Hebrew Language and the Shrine of the Book 1973) 39; http://bensira.org/navigator.php?Manuscript=B\&PageNum=27 [accessed on 8 July 2018]. Cf. Askin, Scribal Culture in Ben Sira, 187; I. Lévi, The Hebrew Text of the Book of Ecclesiasticus (Semitic Study Series; Leiden: Brill 1904) 44; Peters, Das Buch Jesus Sirach oder Ecclesiasticus, 310-312; idem, Hebräische Text des Buches Ecclesiasticus (Freiburg im Breisgau: Herdersche Verlagschandlung 1902) 156; P.W. Skehan -A.A. Di Lella, The Wisdom of Ben Sira (The Anchor Bible 39; New York - London - Toronto: Dou- 
The translation of Sir 38:1-3 was based on the critical edition of the Greek version of Sir, published in 1980 by Ziegler. ${ }^{53}$

38:1 Honor the doctor for his necessity, ${ }^{54}$

since indeed the Lord created him;

38:2 For healing comes from the Most High, and he will receive a gift from king.

38:3 A physician's skill will put up his head and in the presence of nobles he will be admired. ${ }^{55}$

bleday 1987) 439; R. Smend, Die Weisheit des Jesus Sirach erklärt (Berlin: Reimer 1906) 338-339; Zapff, Jesus Sirach 25 - 51, 253-254. "Interessant ist, daß in diesem Abschnitt häufig die Randlesarten des hebräischen Textes (Hmarg) die besseren Varianten bieten in Übereinstimmung mit G und S" (J. Marböck, Weisheit im Wandel. Untersuchungen zur Weisheitstheologie bei Ben Sira [BZAW 272; Berlin - New York: de Gruyter 1999] 154).

On the translation of the Hebrew text see Adinolfi, "Il medico in Sir 38,1-15," 174; Askin, Scribal Culture in Ben Sira, 188; Lührmann, "Aber auch Arzt gib Raum (Sir 38,1-15)," 57-58; Mazzinghi, "«Poi fa' posto al Medico, perché ti è necessario» (Sir 38,1-15)," 66; C. Mopsik, La Sagesse de ben Sira (Les Dix Paroles; Paris: Verdier 2003) 217-218; V. Morla, Los manuscritos hebreos de Ben Sira. Traducción y notas (Asociación Bíblica Española 59; Estella: Editorial Verbo Divino 2012) 219; Skehan - Di Lella, The Wisdom of Ben Sira, 438; http://bensira.org/navigator. php?Manuscript=B\&PageNum=27 [accessed on 8 July 2018]. Cf. A. Minissale, Siracide (Ecclesiastico), 3rd ed. (Nuovissima Versione della Bibbia 23; Cinisello Balsamo: San Paolo 2002) 178; S. Noorda, "Illness and Sin, Forgiving and Healing: The Conception of Medieval Treatment and Religious Beliefs in Ben Sira 38,1-15," Studies in Hellenistic Religions (ed. M. Vermaseren) (Études Préliminaires aux Religions Orientales dans L'Empire Romain 78; Leiden: Brill 1979) 219, footnote 9; Palmisano, Siracide, 342-343; Peters, Hebräische Text des Buches Ecclesiasticus, 384; R. Smend, Die Weisheit des Jesus Sirach hebräisch und deutsch (Berlin: Reimer 1906) 65; J. Vella, "Eclesiastico," La Sagrada Escritura. Texto y comentario. Antiguo Testamento. V. Eclesiástico, Isaía, Jeremías, Ezequiel (ed. A.T. Fernández) (Madrid: Editorial Católica 1970) 156.

53 See J. Ziegler, Sapientia Iesu Filii Sirach, 2nd ed. (Septuaginta. Vetus Testamentum Graecum Auctoritate Academiae Scientiarum Gotteingensis editum 12/2; Göttingen: Vandenhoeck \& Ruprecht 1980) 299.

54 The text of Sir 38:1a included in the edition of the Septuagint edited by Rahlfs (Septuaginta. Id est Vetus Testamentum graece iuxta LXX interpretes I-II [Stuttgart: Deutsche Bibelgesellschaft, 1979]

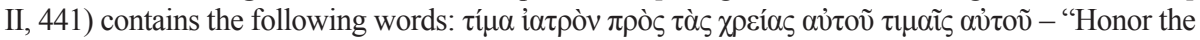
doctor for his necessity through/via his remuneration/fee". It differs from Ziegler's version (Sapientia

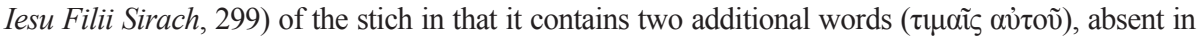
Ziegler's text. Cf. Zapff, "Sir 38,1-15 als Beispiel," 354.

55 On the translation of the Greek text of Sir 38:1-3 cf. Fasce, La lode del medico, 125; W. Kraus - M. Karrer (ed.), Septuaginta Deutsch. Das griechische Alte Testament in deutscher Übersetzung (Stuttgart: Deutsche Bibelgesellschaft 2009) 1141; Ksieggi greckie. Przektad interlinearny z kodami gramatycznymi i indeksem form podstawowych (trans. M. Wojciechowski) (Prymasowska Seria Biblijna; Warszawa: Vocatio 2008) 646-647; Mazzinghi, “«Poi fa' posto al Medico, perché ti è necessario» (Sir 38,1-15)," 66; Noorda, "Illness and Sin, Forgiving and Healing," 218, footnote 9; Palmisano, Siracide, 343; A. Pietersma - B.G. Wright (ed.), A New English Translation of the Septuagint. And the Other Greek Translations Traditionally Included under that Title (New York - Oxford: Oxford University Press 2007) 750; Septuaginta czyli Biblia Starego Testamentu wraz z księgami deuterokanonicznymi i apokryfami (trans. R. Popowski) (Prymasowska Seria Biblijna; Warszawa: Vocatio 2013) 1245. 


\section{The Exegetical Analysis of Sir 38:1-3}

Sir 38:1-3 has a concentric structure. The first and the last verses of this short pericope (38:1 and 38:3) refer to showing respect for the doctor, while the middle one mentions the doctor's being endowed with gifts first by God (38:2a) and then by the king $(38: 2 b)$.

\subsection{A Call to Show Respect to the Doctor (Sir 38:1)}

At the very outset of the pericope devoted to the doctor and his services for the sake of the sick and suffering, Ben Sira performs a "Copernican twist." ${ }^{56} \mathrm{He}$ calls on his listeners to respect the doctor and not to ignore him. According to Fasce, the admonition to "honor" the doctor (Sir 38:1a), positioned at the very beginning of the initial stich of the analyzed pericope, manifests an unexpected turn in the development of the sage's thought. ${ }^{57}$ The admonition is rendered with the use of the imperative form of the present tense ( $\tau \dot{i} \mu \alpha)$. Hence, it does not express an order to be carried out immediately and only once, but a command that should be continued and repeated in the future. ${ }^{58}$ The author advocates in this way the development of a stable attitude that a person willing to acquire wisdom should exhibit towards the doctor and his work. The verb $\tau \mu \mu \alpha \omega$ ("to evaluate," "to assess," "to honor," "to show respect") appears only three more times in the Greek version of the sage's text apart from 38:1a and that is in a pericope devoted to children's obligations towards their parents (see Sir 3:3,5,8). ${ }^{59}$ Ben Sira sees respect shown to one's parents as significant. In 3:3 he maintains that the one who respects his father will have his sins forgiven, he will also rejoice at his offspring and his prayers will be listened to (3:5). Respect to the father needs to be shown not only through words but also through deeds, thanks to which his blessing will be extended to his children who respect their father (3:8). According to the Greek

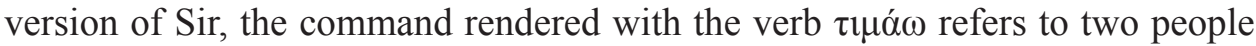

56 "Ben Sira non ha paura di andare contro corrente: nella tradizione biblica, infatti, è il Signore il «medico» di Israele (Es 15,26), eppure, afferma Ben Sira, proprio lui ha «istituito» i medici tra gli uomini"” (Mazzinghi, “«Poi fa' posto al Medico, perché ti è necessario» [Sir 38,1-15]," 69). "Incitando a onorare il medico l'autore ispirato compie un gesto coraggioso che può essere interpretato da qualcuno come un attentato alle prerogative sovrane di Dio in campo terapeutico" (Adinolfi, "Il medico in Sir 38,1-15," 175). Cf. Schrader, "Beruf, Arbeit und Muße,"137-138.

57 See Fasce, La lode del medico, 27.

58 See Piwowar, Skladnia języka greckiego Nowego Testamentu, § 372.

59 See J. Corley, "Respect and Care for Parents in Sirach 3,1-16," Family and Kinship in the Deuterocanonical and Cognate Literature (ed. A. Passaro) (Deuterocanonical and Cognate Literature. Yearbook 2012/2013; Berlin - Boston, MA: De Gruyter 2013) 139-172. 
only. Respect and honor expressed with this word need to be shown primarily to one's own father, but also to the doctor. ${ }^{60}$ While the former case is fully understandable and does not constitute any novelty, as Sir 3:3,5,8 is a practical realization of the forth commandment (see Ex 20:12; Deut 5:16), the admonition to respect the physician is a complete novelty in the Jewish tradition (see section 1). It may then be said that when it comes to the necessity of showing respect and acknowledgement, the doctor is in a way placed in the same position as the father, respect to whom is required by the Law. Like the father, the doctor should enjoy the same, or at least analogous, respect and esteem, not only of moral character, but also of social and material one (in the form of proper remuneration for his work). ${ }^{61}$ Fasce claims that the esteem the doctor should be treated with is only lower than that of the scribe, even though Ben Sira avoids a direct confrontation of these two figures crucial for Israel's society. ${ }^{62}$

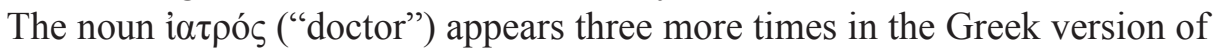
the sage's text apart from 38:1-3. In Sir 10:10 (“A long illness mocks a physician; today a king, and tomorrow he will die") it is somewhat difficult to understand, ${ }^{63}$ and for this reason it is interpreted in a variety of ways by scholars. The majority believe that Sir 10:9-11 refers to the death of Ptolemy IV. ${ }^{64}$ Undoubtedly, the verse positions the physician in a negative light, for on the one hand he shows haughtiness, ignoring a long-lasting disease (10:10a), while on the other he is presented as helpless when faced with a disease he cannot cure and restore health to his patient $(10: 10 \mathrm{~b})$. It needs to be pointed out that the reference to a doctor in 10:10 does not differ from the attitude to the doctor in the whole Jewish tradition, which viewed God as the only one who can possibly heal a person. The verse seems to be pointing to yet another important fact. The doctor appears here not only in the context of disease but also with reference to the person of the king. Does it mean that the sage refers to a doctor who is a member of the royal court, as was common in the Near East at that time? Despite this downright negative reference to a physician (10:10), in 38:1 Ben Sira calls for showing respect and reverence to the doctor. In Sir 38:12a the sage encourages his disciple to, having

60 See Adinolfi, "Il medico in Sir 38,1-15," 157; Sulmasy, "The Covenant within the Covenant," 21.

61 See Fasce, La lode del medico, 27, footnote 32.

62 See Fasce, La lode del medico, 27.

63 "Incerto il senso di Sir 10,10: malattia lunga o malattia breve? É il medico che se la ride della malattia sicuro di vincerla, mentre poi il malato muore? O è la malattia che se la ride del medico portando alla tomba il paziente? Nell'uno o nell'altro caso sono messi in rilievo i limiti della professione medica" (Adinolfi, "Il medico in Sir 38,1-15," 176). Cf. J. Marböck, Jesus Sirach 1 - 23 (Herders Theologischer Kommentar zum Alten Testament; Freiburg - Basel - Wien: Herder 2010) 159; Palmisano, Siracide, 120.

64 See Marböck, Jesus Sirach 1 - 23, 153; T. Middendorp, Die Stellung Jesu Ben Siras zwischen Judentum und Hellenismus (Leiden: Brill 1973); Palmisano, Siracide, 120, 141; J. Schreiner, Jesus Sirach 1 - 24 (Die Neue Echter Bibel. Altes Testament; Würzburg: Echter 2002) 63; Skehan - Di Lella, The Wisdom of Ben Sira, 224-225. 
first called upon God in times of illness, reach out to the doctor (literally "give a doctor a place") and not be afraid of making use of his services, for the doctors were created by God. The stich has a similar, if not identical, resonance as 38:1a. Both of these texts share the same argumentation, expressed with the same words

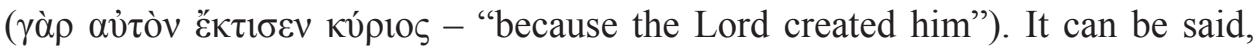
therefore, that Sir 38:12a is a practical realization of the admonition included in 38:1a. ${ }^{65}$ The word i $\alpha \tau$ ó $\varsigma$ appears for the last time in the Greek version of Sirach in Sir 38:15 ("He who sins before him who made him, may he fall into a physician's hands"). Understanding the verse poses a lot of difficulties ${ }^{66}$ Some even believe that it is a later addition, which may constitute a rejection of an earlier positive attitude to doctors and medicine expressed in Sir 38:1-14 ${ }^{67}$ Sir 38:15 seems to suggest that Ben Sira expresses here a traditional view on disease as an outcome of committed evil. ${ }^{68}$

The final part of 38:1a justifies the admonition to respect the doctor: "for his

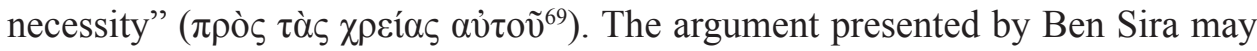
be viewed as pragmatic. Being a realist, he knows that everybody is going to fall sick sooner or later and will need help in having their disease cured and health restored. ${ }^{70}$ For this reason, he encourages his listeners to respect the doctor and not deride him, for when suffering comes, the disciple/listener will seek support and help in doctors, and will have to rely on their abilities and knowledge. ${ }^{71}$

In the second stich of 38:1 the sage presents the following reason for treating

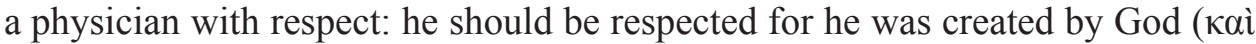

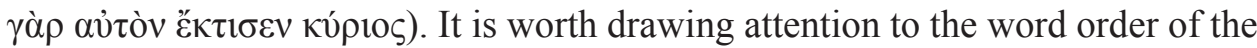

65 See Turkiel, "Septuaginta o lekarzu," 568.

66 See Fasce, La lode del medico, 94; Mazzinghi, “«Poi fa' posto al Medico, perché ti è necessario» (Sir 38,1-15)," 71; Noorda, "Illness and Sin, Forgiving and Healing," 221-222, footnote 18; Schrader, "Beruf, Arbeit und Muße," 142-143; Skehan - Di Lella, The Wisdom of Ben Sira, 443.

67 See Fasce, La lode del medico, 94-95; G. von Rad, La sapienza in Israele (Genova: Marietti 1998) 128, 223. Cf. Marböck, Weisheit im Wandel, 159.

68 See Adinolfi, "Il medico in Sir 38,1-15," 182; Askin, Scribal Culture in Ben Sira, 209; Fasce, La lode del medico, 95-99; Lührmann, "Aber auch Arzt gib Raum (Sir 38,1-15),” 66; Mazzinghi, "«Poi fa” posto al Medico, perché ti è necessario» (Sir 38,1-15)," 71; Marböck, Weisheit im Wandel, 159-160; Schrader, "Beruf, Arbeit und Muße," 142-143; Snaith, Ecclesiasticus, 184; Stöger, "Der Arzt nach Jesus Sirach (38,1-15)," 10; Zapff, Jesus Sirach 25 - 51, 257; idem, "Sir 38,1-15 als Beispiel," 355.

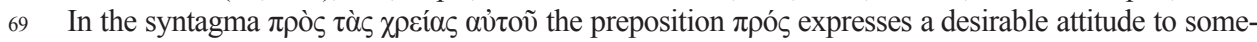

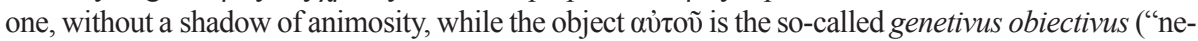
cessity pertaining to the doctor," that is the doctor is the subject of the necessity) on account of the fact that the noun $\chi \rho \varepsilon i ́ \alpha$ etymologically stems from the verb $\chi \rho \eta$ (see R. Beeks, Etymological Dictionary of Greek [Leiden Indo-European Etymological Dictionary Series 10/2; Leiden - Boston, MA: Brill 2010] II, 1647; R. Romizi, Greco antico. Vocabolario greco italiano etimologico e ragionato, 3rd ed. [Bologna: Zanichelli 2007] 1487).

70 See Askin, Scribal Culture in Ben Sira, 193.

71 See Sauer, Jesus Sirach/Ben Sira, 262; Zapff, Jesus Sirach 25 - 51, 253-254; idem, "Sir 38,1-15 als Beispiel der Verknüpfung von Tradition und Innovation bei Jesus Sirach," 359. 
text: direct object, verb and subject. The positioning of the direct object at the beginning of the stich, while it is typically placed after the subject and the verb, seems to indicate the translator's desire to consciously emphasize the figure of the doctor. It seems that it is on the doctor that the stress in the stich falls.

The second argument presented here in favor of treating the doctor with respect and reverence resorts to the highest authority, that is to God (the argument has a theological value; no believer should thus debate or negate it). ${ }^{72}$ This is the ultimate and decisive justification of a doctor's work: he should not be perceived by the Jews as a representative of evil forces (opposing God) but as someone created by God. A doctor is then one of God's creations. It was God himself who wanted the doctor to exist, just like the whole surrounding world. ${ }^{73}$ A doctor is good, like everything else created by God (see Gen 1:31). The sage expresses this truth in a general way, confirming the purposefulness of the world created by JHWH, in a hymn of praise in Sir 39:12-35, ${ }^{74}$ especially in 39:21,31,33. ${ }^{75}$ Everything that has been created is necessary and performs a specific function assigned by God (39:21; cf. 39:28-29). In 39:33 Ben Sira reiterates the idea expressed earlier: "The works of the Lord, all are good, and every need he will supply in its hour." In 42:23 the sage states that all that exists is obedient to its Creator. Further, in 23:20 he maintains that God had already known all that he created prior to the act of creation. According to the idea expressed in $38: 1 \mathrm{~b}$, a doctor is also inscribed in the logic and purpose of the created universe. The words included in this stich are the most important and final justification of the change introduced by the sage when it comes to an attitude to the doctor and his work. Ben Sira perceives the doctor as a work of God. ${ }^{76}$ As it has already been mentioned, the same idea is reiterated in 38:12, as if the sage wanted to inculcate it in the mind of his disciple/reader. It is the first and perhaps the most crucial (fundamental) step to a change of perception on medicine and those who engage in it. They were created by God and they fulfill the role in the society assigned to them by God: they are to offer medical help to every sick person. ${ }^{77}$

The Hebrew text of Sir 38:1 differs from its translation into Greek only in two places, though it has to be conceded that its overtone is the same in both versions.

72 Schrader calls the argument "hochtheologische Begründung" (Schrader, "Beruf, Arbeit und Muße," 136).

73 See Cranz, "Advice for a Successful Doctor's Visit," 242.

74 See J. Liesen, Full of Praise. An Exegetical Study of Sir 39,12-35 (Supplements to the Journal for the Study of Judaism 64; Leiden - Boston, MA - Köln: Brill 2000) 224-275.

75 See Zapff, "Sir 38,1-15 als Beispiel," 359.

76 See Corley, Sirach, 104; Palmisano, Siracide, 343.

77 "Il tono d'apertura è solenne, e l'autore avverte la singolarità di tale esordio, perché si premura di fornire una giustificazione teologica: è il Signore che ha voluto il medico" (Fasce, La lode del medico, 40-41). 
The original does not call on one to respect the doctor (38:1a) ${ }^{78}$ but to maintain a friendly relationship with him. ${ }^{79}$ The main text of manuscript B (Btext) ${ }^{80}$ contains the wording רעי8 (it is an Aramaic form of the imperative of the root hence, it seems to be a later correction ${ }^{82}$ ), while the annotation on the margin (Bmarg) corrects it, suggesting רעה (first person of the imperative Qal of the verb

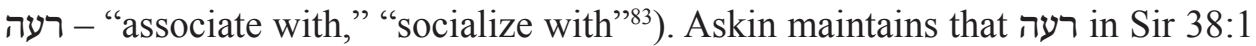
may refer to the remuneration that the doctor deserves for his services. ${ }^{84}$ It seems that such a viewpoint is based more on the reading of the longer version of the

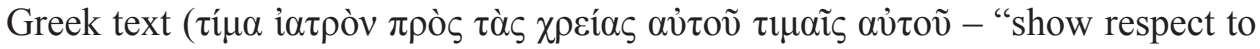
the doctor on account of his necessity, paying his dues [literally through paying him his dues]") than on the original Hebrew text. ${ }^{85}$ The original version of Sir 38:1a does not call on the reader to honor the doctor but to maintain a stable and friendly relationship with him, to form some kind of intimacy. Hence, it does not demand an official attitude towards a physician (that is, respect), as the Greek translation does, but it postulates getting closer to the doctor and treating him as a friend with whom one maintains more intimate and closer relations than with other people. ${ }^{86}$ It does not preclude showing respect and esteem, but this is done not formally or officially, but in a friendly and amiable manner. ${ }^{87}$ It can thus be concluded that the original text suggests a more personal, partner-like and friendly attitude to the doctor than the formal and official treatment proposed by the Greek version, which probably stemmed from the influence of the Alexandrian society and the role of the doctor in it ${ }^{88}$ Fasce views the attitude called for by the

78 "G [translation into Greek] hat dies frei und sinnvoll erklärt" (Stöger, "Der Arzt nach Jesus Sirach [38,1-15]," 4). Peters also believes that the Greek $\tau$ í $\alpha \alpha$ is a free translation of its Hebrew predecessor (see Peters, Hebräische Text des Buches Ecclesiasticus, 156).

79 See Lührmann, "Aber auch Arzt gib Raum (Sir 38,1-15)," 59; Schrader, "Beruf, Arbeit und Muße," 136; Zapff, "Sir 38,1-15 als Beispiel," 354.

80 Sir 38:1a Btext: רעי רופא לפני צרכו. The stich has a somewhat different wording in manuscript D: רעה רועה רופא לפי (cf. Morla, Los manuscritos hebreos de Ben Sira, 388).

81 "Ten consideracion traduce el hebreo $\mathrm{r}^{\mathrm{y}} \mathrm{y}\left(=\mathrm{r}^{\mathrm{h}} \mathrm{h}\right)$, como en el margen y en el ms. D; ejemplos de yôd en lugar de la $h \bar{e}$ ' final se encuentran en los escritos de Qumrân” (Vella, "Eclesiastico," 156). "Für

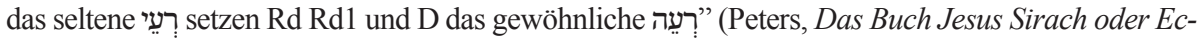
clesiasticus, 311).

82 See Schrader, "Beruf, Arbeit und Muße," 136, footnote 81.

83 Box and Oesterley claim that the Aramaic verb רעה has the same meaning as the Hebrew רצה (see G.H. Box - W.O.E. Oesterley, "The Book of Sirach," The Apocrypha and Pseudepigrapha of the Old Testament in English with Introductions and Critical and Explanatory Notes to the Several Books. I. Apocrypha [ed. R.H. Charles] [Oxford: Clarendon Press 1913] 448).

84 See Askin, Scribal Culture in Ben Sira, 193.

85 See Zapff, "Sir 38,1-15 als Beispiel," 354.

86 As Mazzinghi (“«Poi fa’ posto al Medico, perché ti è necessario» [Sir 38,1-15]," 690) puts it, the Greek version of Sir 38:1a is more decisive and pointed.

87 "Freundliche Gesinnung setzt Hochschätzung und Verehrung voraus" (Stöger, "Der Arzt nach Jesus Sirach [38,1-15]," 4).

88 See Fasce, La lode del medico, 40. 
Hebrew text of Sir 38:1a as consciously opportunistic. ${ }^{89}$ Referring to Lührmann, Zapff explains the difference between the attitude to the doctor proposed in the Hebrew and the Greek version of Sir 38:1a with the use of two arguments. First, during the times of Ben Sira's grandson, doctors were more easily accessible than earlier; secondly, the translator of the original text may have seen some danger in making use of doctors' services, thus he encouraged the readers to respect them but not to foster closer interpersonal relations with them. ${ }^{90}$

The second difference pertains to 38:1b. The original text (גם אתו חלק אל) does not contain the verb ברא ("to create"), which would correspond to the Greek

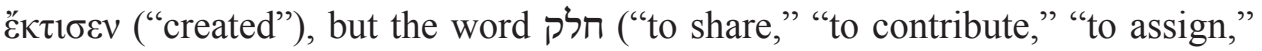
"to divide," "to give sb a part"). ${ }^{91}$ In the Greek version of Sir, the verb חלק was translated five times as $\kappa \tau i \zeta \omega,{ }^{92}$ which may indicate that the meaning of the word became closer to "to create" or that the word started to be understood in this way. ${ }^{93}$ The Hebrew version of $38: 1 \mathrm{~b}$ has a general message. It lacks information on what task God assigned to the doctor or in which he gave him his part. On the basis of $38: 1$ a one can easily deduce that the task in question is that of healing people, of helping them regain strength, of removing their pain and suffering, for these were the tasks of the physician..$^{94}$ If such an interpretation based on logical deduction is accurate, this would mean that the Hebrew text emphasizes more clearly and strongly the fact that the doctor does not represent forces opposing God; on the contrary, his role of healing people and alleviating their pain is a task assigned to him by God himself. ${ }^{95}$ The original version would then express in a straightforward way the fact that God - the only one who can truly heal a person - gave the doctor a part to play in his task of curing the diseases people suffer from. ${ }^{96}$ A doctor would then be not so much God's helper, but rather his messenger and

89 See Fasce, La lode del medico, 39.

90 See Zapff, "Sir 38,1-15 als Beispiel," 354.

91 See Askin, Scribal Culture in Ben Sira, 193; Cranz, "Advice for a Successful Doctor's Visit," 242; Marböck, Weisheit im Wandel, 156; F.V. Reiterer, "Alle Weisheit stammt vom Herrn...". Gesammelte Studien zu Ben Sira (BZAW 375; Berlin - New York: de Gruyter 2007) 186, 330; Schrader, "Beruf, Arbeit und Muße," 136; Zapff, "Sir 38,1-15 als Beispiel," 359.

92 See Sir 7:15b; 31:27d; 39:25a; 40:1a and 44:2a. "Molti traduttori preferiscono il testo greco che parla di 'creato'. Ma l'ebraico halak non significa mai creare, bensì 'spartire' tra diverse persone. É meglio attenersi al testo ebraico, piché l'idea di una 'parte' attribuita da Dio all'uomo è attestata nella letteratura didattica (eccle 2,10.21; 3,22, ecc.)” (von Rad, La sapienza in Israele, 126, footnote 26). Cf. Box - Oesterley, "The Book of Sirach," 448-449.

93 See Duesberg, "Le médecin, un sage," 44-45; Skehan - Di Lella, The Wisdom of Ben Sira, 441. Cf. Schrader, "Beruf, Arbeit und Muße," 136.

94 See Adinolfi, "Il medico in Sir 38,1-15," 177; Zapff, Jesus Sirach 25 - 51, 254.

95 See Zapff, "Sir 38,1-15 als Beispiel," 359-360.

96 See Adinolfi, "Il medico in Sir 38,1-15," 177; Lührmann, "Aber auch Arzt gib Raum (Sir 38,1-15)," 59; Marböck, Weisheit im Wandel, 157. 
a tool in his hands. ${ }^{97}$ Zapff terms a doctor an earthly substitute of the Lord. ${ }^{98} \mathrm{In}$ his view, the Greek translation of Sir 38:1 a dilutes and obliterates the message of the original stich, while the Hebrew text reflects Ben Sira's openness to a stoic idea of the world's order. ${ }^{99}$

\subsection{Rewarding the Doctor (Sir 38:2)}

Having expressed his revolutionary opinion on the doctor, in 38:2a Ben Sira on the one hand continues the thought expressed in $38: 1 \mathrm{~b}$ about the divine provenance of the physician, while on the other he refers to the traditional perception of curing an illness and regaining health, theologically rooted in the Old Testament. The sage develops the idea of the doctor's provenance expressed earlier ("God created him" - 38:1b), directly claiming that the outcome of a doctor's work originates from the same source as he himself, that is from God: "for heal-

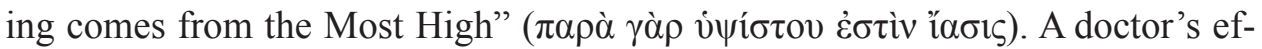
forts are aimed at curing a patient, but the effect of the therapy does not depend only on him. At the end of the day, it is the Most High who heals. ${ }^{100}$ Alluding to the idea of healing accepted earlier and rooted in the theology of the Old Testament, Ben Sira confirms in this way that God is the only one who heals and restores health. Hence, the doctor plays the role of an intermediary in passing the precious gift to the sick: he is merely a tool in God's hands, having been created to aid people in returning to health and strength. ${ }^{101}$ According to Ben Sira's view of the doctor and his work, the physician is fully dependent on God and his will regarding illness and its complete cure. In other words, it is not the doctor and the treatment prescribed by him that restore health to the sick one, but the Lord. This is corroborated also by the fact that the preposition $\pi \alpha \rho \alpha$ in 38:2a may be translated as "thanks to." This further emphasizes the role that the Greek version of the stich under study here ascribes to God in the process of healing. The syntagma $\pi \alpha \rho \alpha ̀$ vi $i ́ \sigma \tau o v$ appears in the Greek text of Sir three more times apart from 38:2a. Verse 12:2 mentions the fact that if a man does good to a pious one, he will receive a reward ("repayment" - $\alpha \nu \tau \alpha \pi \delta \delta \delta \rho \alpha$ ), if not from the beneficiary,

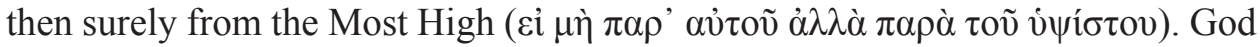
can speak to a man through dreams and nightly visions. If they do not come from God, however, one should not pay attention to them or abide by them (34:6). Sir 50:21 describes the behavior of the people (bowing down to worship) who

\footnotetext{
97 See Cranz, “Advice for a Successful Doctor's Visit," 243.

98 See Zapff, "Sir 38,1-15 als Beispiel," 360.

99 See Zapff, "Sir 38,1-15 als Beispiel," 359.

100 See Stöger, "Der Arzt nach Jesus Sirach (38,1-15)," 4-5.

101 See Mazzinghi, “«Poi fa’ posto al Medico, perché ti è necessario» (Sir 38,1-15),” 69.
} 


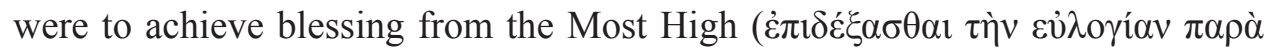
vifítov). ${ }^{102}$ What is worthy of note in the context of 38:2a is the final text including the expression $\pi \alpha \rho \alpha$ vi the description of the figure and activity of High Priest Simon, who is presented while performing liturgic activities. The description ends with a solemn blessing bestowed on the whole nation by God through the high priest. On the basis of the

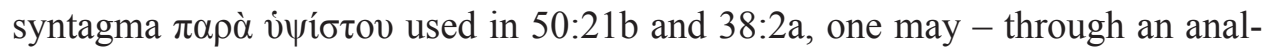
ogy - compare the intermediation of the high priest and the doctor on behalf of the people. The former conveys a blessing that is bestowed by God, while by the same token the latter acts as a go-between in God's healing of a sick person. It

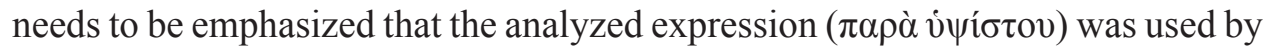
the translator of Ben Sira's work only to express God's gift of good and positive realities (a reward; a nightly vision that helps understand one's situation and find a solution; healing and blessing).

The noun íarc ("healing," "curing") stems from the same root $i \alpha$ ("to treat," "to heal") that forms part of i $\alpha \tau \rho$ ó $\varsigma$ ("doctor"). The first of these words was formed through the addition to the root of the suffix - $\sigma 1 \varsigma$, which expresses an activity and its outcome; the second one, in turn, was created through the addition to the root $i \alpha$ of the suffix - $\tau \rho o s$, indicating the person performing the activity. ${ }^{103}$ Etymologically, then, these two words are closely related and they stem from the same activity (treating/healing). In the Greek text of Sir 'ícıs appears seven more times apart from 38:2a. Sir 38:14 confirms the truth expressed in the analyzed stich that healing comes from God. Verse 1:18b likewise states that good

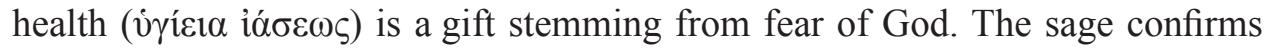
this truth one more time in 34:17, stating that it is God who gives a man health,

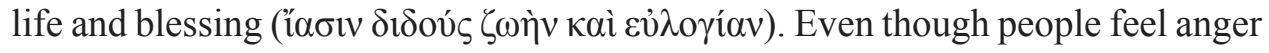

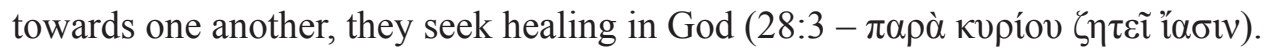
The word íaris is used three times in a metaphorical sense, and not with reference to health and healing. Twice, it refers to the curing of evil that somebody may commit (spiritual healing): in 3:28 pride and haughtiness are mentioned in this context, while in 21:3 - depravity. There is no treatment for these illnesses of a person's spirit, and they cannot be cured. The noun í $\alpha \sigma 1 \zeta$ is used in a figurative way also in 43:22, where it denotes fog and dew as a remedy for drought and scorching heat. In all of his teachings Ben Sira clearly underscores the thought expressed in $38: 2 \mathrm{~b}$ that a cure of bodily ailments comes only from God and only God can offer help and solace to the suffering one.

102 See O. Mulder, Simon the High Priest in Sirach 50. An Exegetical Study of the Significance of Simon the High Priest as Climax to the Praise of the Fathers in Ben Sira's Concept of the History of Israel (Supplements to the Journal for the Study of Judaism 78; Leiden - Boston, MA: Brill 2003) 192-201.

103 See Beeks, Etymological Dictionary of Greek, I, 573; Romizi, Greco antico, 626-627. 
At first glance, Sir 38:2b seems not to fit the context established by the two preceding stichs (38:1b and $2 \mathrm{a})$ that speak of the doctor and the source of healing, namely God. Ben Sira maintains in this stich that the doctor "will receive

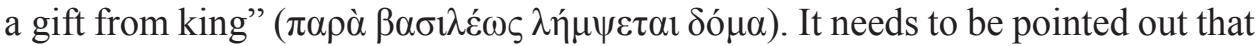
both stichs of 38:3 begin in the same way: $\pi \alpha \rho \alpha$ + genetivus, which indicates the person that gives something that the doctor receives. In the first part of 38:2 he receives the cure for the patient's ailments, while in the second - a gift from the king. The noun $\delta$ ó $\mu \alpha$ ("gift") appears two more times in the Greek text of Sirach (see 7:33 and 18:17). It always refers to something that a man gives to another man and it seems that it refers to material rather than spiritual things. In 38:2b the gift needs to be of a material character - money or valuables - as remuneration for the doctor's services. ${ }^{104}$

In the Greek version of Sir the noun $\beta \alpha \sigma \imath \lambda \varepsilon$ cu ("king") always refers to a human ruler, with the exception of 51:1. ${ }^{105}$ In 7:4 the sage admonishes his readers not to seek glory next to the ruler (literally "the seat of honor" - $\kappa \alpha \theta \varepsilon \dot{\varepsilon} \delta \rho \alpha \nu \delta$ ó $\xi\rceil$ ), while in 7:5 he warns against demonstrating wisdom in front of the monarch ( $\mu$ ทे бoфí̧ov). Ben Sira cautions his disciple/reader not to show off in the presence of the king for it may bring disastrous consequences. The situation presented in $38: 2 \mathrm{~b}$ is completely different. The doctor does not wish to show off his abilities in front of the monarch, but his professional activity is acknowledged and rewarded: it is honored with a gift. As it has been pointed out earlier, Sir 10:10 also suggests the presence of the doctor at the royal court. Verse 38:2b corroborates this assumption. ${ }^{106}$ The text does not directly mention the doctor's remuneration for his work aimed at restoring health, but the context suggests that in an obvious and clear way (verse 38:2a speaks of healing). In Lührmann's view, the doctor is not an ordinary royal official or craftsman, but is treated in an exceptional way, with extraordinary kindness and respect. ${ }^{107}$ It may come as a surprise that Ben Sira mentions the king and his court, for in his times there was no king in Israel, with the high priest performing highest religious and lay power. Speaking of the king and the presence of the doctor in the king's entourage, the sage may have referred to the situation in the neighboring nations, whose rulers had royal physicians at their disposal. Ben Sira knew that from his own experiences, on account of his numerous travels.

What may come as a surprise is the form of the future tense $\left(\lambda \eta \mu \psi \varepsilon \tau \alpha_{l}\right.$ - "will receive") used instead of the present tense. Maybe it should be treated as futurum

104 See Lührmann, "Aber auch Arzt gib Raum (Sir 38,1-15)," 60.

105 See Sir 7:4.5; 8:2; 10:3,10; 45:3,25; 46:20; 47:11; 48:6,8,23; 49:4 and 51:6. Cf. Box - Oesterley, "The Book of Sirach," 449.

106 See Askin, Scribal Culture in Ben Sira, 194; Skehan - Di Lella, The Wisdom of Ben Sira, 441; Zapff, Jesus Sirach 25 - 51, 254.

107 See Lührmann, “Aber auch Arzt gib Raum (Sir 38,1-15)," 60. 
gnomicum, that is present tense that pertains to a commonly upheld rule (when the doctor heals the king or somebody close to him, or aids them in their suffering, he always receives some gift from them). ${ }^{108}$ It may also be assumed that $\lambda \eta \mu \psi \varepsilon \tau \alpha \iota$ refers to the future healing of the monarch or his kin, even though the first interpretation seems more plausible and natural.

It is worth emphasizing a symmetry of a kind visible in the form of $38: 2$, as noticed above ( $\pi \alpha \rho \alpha$ + genetivus of a person + what is given), since on the one hand it seems intentional and, on the other, it expresses an important truth about the doctor. ${ }^{109}$ A certain parallelism exists in a doctor's life: he receives from God a positive outcome of his work (healing), and from the king - remuneration for his work, which is the basis of his sustenance. The doctor is thus presented as a person that is dependent on others, primarily on God, ${ }^{110}$ as it is God who causes the fortunate result of the doctor's work, thanks to which he can satisfy the material needs of himself and his family. The doctor was not only created by God, but it is God that the effect of his work depends on. In the material sphere, by contrast, the doctor depends on the king that he serves. The doctor's contingency on God and king is emphasized by the concentric structure of Sir 38:1-3, in which Sir 38:2 is positioned in the center, expressing the main idea of the whole unit (A: 38:1 - respect for the doctor; B: 38:2 - the doctor's dependence; A': 38:3 respect for the doctor).

The beginning of my analysis of Sir 38:2b draws attention to a radical change of context between 38:2a (God - theological context) and 38:2b (king - lay context). The introduction of the figure of the monarch rewarding the doctor in the second stich of the verse seems to be an allusion to the first stich of the whole pericope (38:1a), in which the reader is encouraged to show respect to the doctor. Since the physician is rewarded by the king in the form of gifts (remuneration) for a satisfactory realization of his duties, he should likewise enjoy acknowledgment from the remaining part of the society, that is ordinary people. ${ }^{111}$ In this way, verse $38: 2 \mathrm{~b}$ becomes another argument - this time a non-theological one - proving the necessity for showing respect and honor to the doctor as well as a reason to make use of the doctor's services. ${ }^{112}$ If the monarch subjects himself to the doctor's treatment, there is no reason others should not do the same. In this way, the king legitimizes and justifies the doctor's services. He shows the propriety and necessity of seeking a doctor's help in times of disease.

\footnotetext{
108 See Piwowar, Składnia języka greckiego Nowego Testamentu, § 360.

109 See Schrader, "Beruf, Arbeit und Muße," 138.

110 See Zapff, Jesus Sirach 25 - 51, 254.

111 See Askin, Scribal Culture in Ben Sira, 194; Palmisano, Siracide, 343; Sauer, Jesus Sirach/Ben Sira, 262; Schrader, "Beruf, Arbeit und Muße," 138

112 "Da avversario che occorre combattere il medico è divenuto ormai prezioso alleato" (Mazzinghi, “«Poi fa' posto al Medico, perché ti è necessario» [Sir 38,1-15],” 69).
} 
The Hebrew text of Sir 38:2 differs from the Greek version only in the first stich. ${ }^{113}$ The difference lies in what the doctor receives from God. The Greek version mentions healing, while the original text - wisdom (מאת אל יחכם רופא literally "from God the doctor becomes wise/acts wisely"114; on this basis, Zapff maintains that the main subject matter of Sir 38:2 are the doctor's abilities ${ }^{115}$ ). Both versions agree on who the doctor's activity depends on and from whom he receives the gift pertaining to his work: it is God. ${ }^{116}$ The two versions of the text differ in specifying what comes from God and what the doctor receives from God. ${ }^{117}$ The Greek translation concentrates on the effect of the doctor's activity, that is on healing, while the Hebrew original seems to underscore the foundation of the doctor's work, that is his wisdom. ${ }^{118}$ It is thanks to his wisdom that he can act as a doctor. What the physician received from God is wisdom, that is knowledge about and abilities to treat various maladies, and for this reason he may aid patients in their suffering and help them regain their health and strength. The sage posits that these capabilities and competences are not merely an outcome of studies and experience, but they are gifts from God. ${ }^{119}$ Both versions of Sir 38:2a share the belief in the contingency of the doctor's activity on God, but they accentuate its different stages: the process of healing or therapy is emphasized by the original version, while its translation into Greek stresses the final effect (that is, healing). ${ }^{120}$

It needs emphasizing that the original version of the analyzed stich is in accord with the sage's initial declaration that all wisdom originates from God (1:1: $\pi \tilde{\alpha} \sigma \alpha$

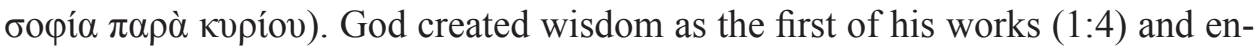
dowed every creature with it (1:10; longer Greek version) ${ }^{121}$ However, wisdom is attained by a few only $(6: 22),{ }^{122}$ the scribe being one of them $(38: 1 ; 39: 1-11) .{ }^{123}$

113 Sir 38:2b (ומאת מלך ישא משאות) is fully in accord with its Greek translation. Cf. Askin, Scribal Culture in Ben Sira, 194; Mopsik, La Sagesse de ben Sira, 218, footnote 2; Morla, Los manuscritos hebreos de Ben Sira, 219, footnote 5; Schrader, "Beruf, Arbeit und Muße," 138.

114 Morla (Los manuscritos hebreos de Ben Sira, 219, footnote 4) translates the stich in the following way: "de parte de Dios actúa sabiamente el medico". C. Mopsik (La Sagesse de ben Sira, 218, footnote 1): "De par Dieu le médecin devient sage".

115 See Zapff, "Sir 38,1-15 als Beispiel," 360.

116 See Adinolfi, "Il medico in Sir 38,1-15," 177.

117 See Zapff, "Sir 38,1-15 als Beispiel," 354.

118 Di Lella argues that 38:2a places a strong emphasis on the doctor's wisdom (see Skehan - Di Lella, The Wisdom of Ben Sira, 441).

119 Mazzinghi (“«Poi fa' posto al Medico, perché ti è necessario» [Sir 38,1-15],” 69) defines the doctor's wisdom as an ability to coherently connect in his life his innate, natural abilities with gifts from God.

120 See Zapff, "Sir 38,1-15 als Beispiel," 354.

121 See A. Piwowar, "Początkowa koncepcja mądrości według Syracha. Syr 1,1-10 jako perykopa programowa," BibAn 4/2 (2014) 405-407, 414-418, 435-442; Zapff, "Sir 38,1-15 als Beispiel," 360.

122 See Piwowar, "Zdobycie mądrości według Syracha (Syr 6,18-37)," 131-134.

123 See A. Piwowar, "Uczony w Piśmie -ideał człowieka poszukującego mądrości (Syr 38,24; 39,1-11)," BibAn 6/4 (2016) 527-600. 
In the conclusion of his work, Ben Sira maintains that he has achieved wisdom and thus he can convey it to others $(51: 13-30) .{ }^{124}$ Due to his wisdom granted him by God, the doctor belongs to an exceptional group of those who try to attain wisdom and behave in accord with its precepts. ${ }^{125}$ In the sage's point of view, the only other person of that kind is the scribe. ${ }^{126}$ It is with reference to these two professions only that Ben Sira speaks of an exceptional position of wisdom in their lives and professional activities. ${ }^{127}$ Due to this fact, it can be claimed that by implicitly comparing these two groups with each other Ben Sira elevates the doctor above all the other social groups. ${ }^{128}$ The doctor is not like other craftsmen: even though they possess exceptional and great abilities (38:31-32), they were not granted wisdom by God (38:25), and for this reason they do not act as intermediaries between God and people, in contrast to the scribe and the doctor (38:33-34). ${ }^{129}$ According to the Hebrew version, this is the basis for the social and religious position of the doctor and the reason why he should be treated with respect and reverence. ${ }^{130}$

The changes introduced in the translation of the original text by Ben Sira's grandson may have stemmed from social conditions and the addressees of the Greek version of Sir (Hellenized Jews and Greeks). It may be assumed that if the Greek text of Sir 38:2a mentioned wisdom, it would present the physician more as a philosopher than as a professional engaged in curing patients and probing the secrets of the human body. For this reason, the Greek version concentrates more on the effects of the doctor's work (healing) than on his wisdom, which was associated by the Greeks more with philosophers than with doctors. What is more, Greek medicine, based on empirical rather than spiritual precepts, was to a large extent (albeit not completely) severed from the sphere of religion and faith. The translation of the analyzed stich into Greek was supposed to function getyczno-teologiczna Syr 51,13-30,” BibAn 4/1 (2014) 57-96.

125 "Er [the doctor] ist ein Weiser, der seine Weisheit von Gott selber bekommt (v. 2a); was er tut, ist also in Übereinstimmung mit Gottes die Welt gestaltender und im Gesetz dokumentierter Weisheit. Den Beweis dafür liefert die soziale Reputation des Arztes, denn auf ihn trifft all das zu, was sonst für den Weisen gilt. Damit wird hier erstmals gegenüber der Tradition die Medizin zu einem Teil der Weisheit" (Lührmann, “Aber auch Arzt gib Raum [Sir 38,1-15]," 59-60).

126 See Zapff, "Sir 38,1-15 als Beispiel," 360.

127 "It is significant that the verb חכם is found in Sir 38,2, since this links wisdom to the knowledge of physicians. One of the aims of advanced scribal education is to learn wisdom, so attributing wisdom to physicians is powerful" (Askin, Scribal Culture in Ben Sira, 194). Cf. Duesberg, "Le médecin, un sage," 45.

128 See Adinolfi, "Il medico in Sir 38,1-15," 177; Schrader, "Beruf, Arbeit und Muße," 138.

129 See Lührmann, "Aber auch Arzt gib Raum (Sir 38,1-15)," 61; Schrader, "Beruf, Arbeit und Muße," 138.

130 See Zapff, Jesus Sirach 25 - 51, 254. 
as a reminder of the theological truth about God as the only one who heals and cures all the maladies.

Schrader believes that the text that Ben Sira's grandson had at his disposal read יחלם instead of יחלם "to become strong," "to restore health"). ${ }^{131}$ This is a mere assumption based solely on the similarity of the two forms and on the translation of 38:2a into Greek and Syrian, which has no corroboration in the original text known today.

\subsection{Respect for the Doctor on the Part of Rulers and Dignitaries (Sir 38:3)}

The final verse of the pericope analyzed here contains yet another argument justifying respect and honor that should be shown to the doctor. ${ }^{132}$ First, Ben Sira

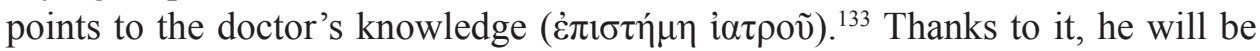
raised over other people ( $\dot{\alpha} v \psi \psi \omega ́ \sigma \varepsilon 1 \kappa \varepsilon \varphi \alpha \lambda \eta े \nu \alpha u ̛ \tau o \tilde{)})$, that is he will occupy a significant position in the society. ${ }^{134}$ On account of his education, he will also be

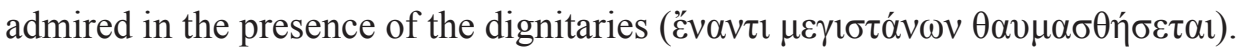

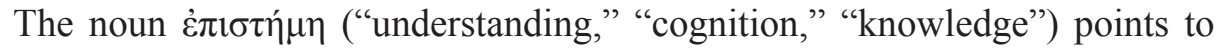
the doctor's knowledge and his cognitive abilities: first to an ability of insightful observation and then to the sagacity of his mind which enables him to draw proper conclusions. ${ }^{135}$ In the Greek version of Ben Sira's text the word appears fifteen more times apart from 38:3a. The Greek translation of the sage's text emphasizes six times the fact that God gave knowledge to people. It is a gift that God generously bestows on those who fear him (1:19). He filled people with knowledge and sensibility $(17: 7,11)$. Ben Sira stresses this truth one more time in 38:6. Together with the law, Moses was given wisdom (45:5). Sir 33:11 states that God has complete knowledge and thus he can give it to whomever he wants to and to the degree he has determined. Knowledge is closely related to wisdom (1:25; cf. 19:22). It is on account of knowledge that even a pauper is praised (10:33). A wife ensures the prosperity of the whole family thanks to her knowl-

131 See Schrader, "Beruf, Arbeit und Muße," 138, footnote 88.

132 See Lührmann, "Aber auch Arzt gib Raum (Sir 38,1-15)," 60; Schrader, "Beruf, Arbeit und Muße," 138.

133 "The opening words רופא יחכם recall Sir 38:2, further cementing the theme that the physician is wise and learned" (Askin, Scribal Culture in Ben Sira, 195).

134 See Fasce, La lode del medico, 32; Lührmann, “Aber auch Arzt gib Raum (Sir 38,1-15),” 60.

135 "Wiedza z całą pewnością stanowi element składowy mądrości. Wydaje się, że jest jej fundamentem - trzeba najpierw coś poznać, wiedzieć, aby następnie móc to realizować w swym życiu. Jest przejawem mądrości, choć nie utożsamia się z nią” (Piwowar, “Uczony w Piśmie," 574). 
edge (26:13). Knowledge characterizes also the scribe (39:7). ${ }^{136}$ Ben Sira claims that he has acquired knowledge and thus he can convey it in his work (16:25 and 50:27). Therefore, he calls on his disciple/listener to attain knowledge as well and to possess cognition/understanding (16:24). It needs to be emphasized that, as the Jerusalem sage sees it, knowledge is not only an outcome of intellectual cognition and accumulation of information, that is, it is not erudition. Referring to and linking it with wisdom (without specifying the relations between them), the Law and the knowledge of good and evil, the sage transfers knowledge to the religious/spiritual sphere. This is also confirmed by the fact that he presents knowledge primarily as a gift from God, and not a result of somebody's rational and intellectual explorations and inquiries. ${ }^{137}$

Attributing $\dot{\varepsilon} \pi \sigma \tau \eta \dot{\mu \eta}$ to the doctor, Sirach on the one hand claims that the doctor is an exceptional person, once more put alongside the scribe and presented in a way as a sage (on the basis of a close relation of knowledge/cognition and wisdom). ${ }^{138}$ On the other hand, however, he confirms the physician's dependence on God in his work, for it is God that endows him with knowledge and understanding. ${ }^{139}$ This is not the end of the role played by knowledge in the doctor's

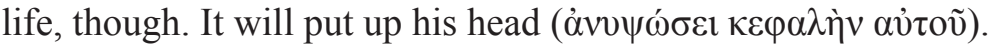

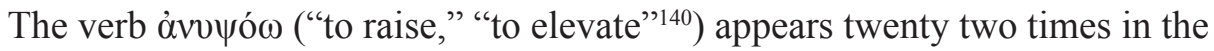
Greek text of Sir apart from 38:3a. Its subject may be God $(1: 19 ; 7: 11 ; 11: 13$; $24: 13,14 ; 33: 9,12 ; 34: 17 ; 44: 21 ; 47: 11)$, wisdom $(4: 11 ; 11: 1)$, a man $(13: 23$; $20: 28 ; 21: 20 ; 46: 20 ; 47: 5 ; 49: 12 ; 51: 9)$, and wealth $(28: 10 ; 40: 26)$. The direct objects of the verb are varied: a God-fearing man (1:19), the sage (4:11), a humble one (11:1) or one that lacks strength (11:13), the words of the rich (13:23), piles of harvest (20:28), voice $(21: 20 ; 46: 20)$, wisdom $(24: 13,14)$, anger $(28: 10)$, some days (33:9), some people (33:12), human spirit (34:17; 40:26), Abraham's offspring (44:21), the might of the people (47:5), David's power (47:11), the tabernacle (49:12), and begging (51:9). Generally speaking, when God is the subject of the elevation, it brings favorable consequences to a person, but if the subject is a human being - elevation leads to negative consequences. To more precisely determine the outcome of the elevation of the doctor's head through his knowledge, three texts need to be paid attention to. Sir 1:19 similarly to 38:3a speaks about knowledge and elevation. Knowledge is not the elevating subject, for God

136 See Piwowar, "Uczony w Piśmie," 573-575.

137 See Skehan - Di Lella, The Wisdom of Ben Sira, 441.

138 See Lührmann, "Aber auch Arzt gib Raum (Sir 38,1-15)," 60.

139 "Was Arzt und Schriftgelehrter gemeinsam haben, ist auch daß sie ihre Weisheit Gott selber verdanken und zu Gott beten" (Lührmann, "Aber auch Arzt gib Raum [Sir 38,1-15]," 61).

140 See H.G. Liddell - R. Scott, A Greek-English Lexicon, 10th ed. (Oxford: Clarendon Press 1996) 168; F. Montanari, Vocabolario della lingua greca, 2nd ed. (Torino: Loescher 2004) 256; Muraoka, A Greek-English Lexicon of the Septuagint, 61. 
performs the elevation. It is a gift from God to the one who fears him. The man receives knowledge from the Most High and God elevates the one who fears him. A similar, though less explicit, dependence is expressed also in 38:3a. The doctor's knowledge, which he received from God, causes his elevation. It can be said, then, that JHWH indirectly elevates the physician above others by granting him knowledge. Cognition/understanding is thus a tool through which God elevates the doctor. It is God's indirect activity (expressed implicitly). The expression

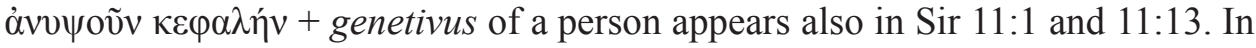
the first of these texts the pauper's wisdom is the subject of the activity, while in the second - it is the Lord. On the basis of the deployment of the syntagma in the Greek version of Sir, it may be unequivocally claimed that its effects are positive for the man whose head is elevated. In 11:1 the elevation of the head is a synonym of occupying an honorable place among the mighty, that is of a man's ennoblement despite his material poverty. ${ }^{141}$ In $11: 13$, in turn, it signals elevation from degradation, which causes astonishment and exaltation. The elevation/putting up of the doctor's head due to his knowledge needs to be read in the context of these two verses. Knowledge safeguards an honorable position for the doctor in the society and generates admiration in other people, who commend the doctor's medical knowledge and ability to cure the suffering. ${ }^{142}$ The reading of the syntagma "the putting up of the head" in the sense of a man's elevation finds its confirmation in Sir 20:11, which also speaks of the elevation of the head after prior debasement. On the basis of Ps 110:7, Zapff views the raising of the head as a posture befitting the king, ${ }^{143}$ while Stöger mistakenly claims that the doctor's head is raised by God. ${ }^{144}$ Both in the Hebrew text and its translation into Greek the subject of the verb "to put up/to elevate" is the physician's knowledge. God only contributes to this through granting the doctor cognition/understanding. $\mathrm{He}$ is thus an indirect cause of the elevation of the doctor's head.

The second stich of 38:3 also expresses an exceptionally honorable and revered position of the doctor in the society. It continues in the form of synonymic parallelism the description of respect that the doctor enjoys among his contemporaries. He will be admired $(\theta \alpha v \mu \alpha \sigma \theta \eta ́ \sigma \varepsilon \tau \alpha \imath)$ among higher social spheres

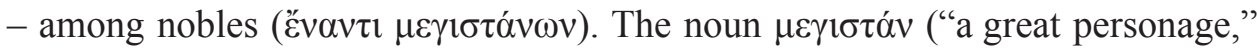
"a noble," "a dignitary") appears in the Greek text of Sir eleven more times apart from $38: 3 \mathrm{~b}$. The sage confirms the high position in the social hierarchy occupied by people defined with this term, and for this reason he encourages his disciples to respect them (4:7) and cautions them against attempting to be equal to dignitaries and nobles (32:9). A dignitary will be praised alongside the judge and

\footnotetext{
141 See Lührmann, “Aber auch Arzt gib Raum (Sir 38,1-15),” 60.

142 See Box - Oesterley, "The Book of Sirach," 449.

143 See Zapff, Jesus Sirach 25 - 51, 254.

144 See Stöger, "Der Arzt nach Jesus Sirach (38,1-15)," 5.
} 
the ruler, but one who fears God enjoys an even greater recognition (10:24). The fact that the noble is mentioned alongside the judge and the ruler testifies to the fact that they belonged to elites leading the community, as corroborated also by 33:19, where they are mentioned together with leaders of the congregation. The dignitaries were surrounded by people who did various favors for them $(8: 8)$. Those who supported and helped them included also the scribe $(39: 4){ }^{145}$ A reasonable man would naturally wish to ingratiate himself with them and gain their mercy (20:27); he may then even be granted forgiveness for the depravity he has committed (20:28). The nobles possess substantial power and may have a positive or negative impact on the life of an ordinary person, hence the sage calls on his readers to behave properly in the presence of the dignitaries so as not to evoke their wrath and punishment (23:14). The nobles' powerful position, however, is not beyond jeopardy. For example, slander can bring their house to ruin (28:14). In the context of the analysis of $38: 3 b$, verse $11: 1$ is again of great importance (see above). Ben Sira claims in it that "a humble person's wisdom

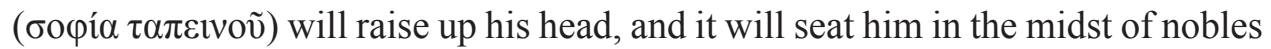
( $\dot{\varepsilon} v \mu \varepsilon \dot{\varepsilon} \sigma \omega \mu \varepsilon \gamma(\sigma \tau \dot{\alpha} v \omega v)$." The text maintains that the dignitaries pay attention to a man's wisdom, and he can find a place among them on its account. He does not become one of them, but he socializes with them, which is in itself a great honor and nobilitation. ${ }^{146}$ The doctor's case is analogous. His knowledge makes him associate with the nobles and be admired by them. It needs to be emphasized that the physician occupies a similar position among the nobles as the scribe. Ben Sira again puts these two figures alongside each other. ${ }^{147}$ Now it seems that the indirect comparison of the doctor with the scribe shows the first one as more worthy of respect and honor, for he is admired by the nobles, while the scribe is depicted as the one who serves them.

The verb $\theta \alpha u \mu \alpha ́ \zeta \omega$ ("to admire," "to honor," "to revere") expresses the attitude of astonishment and awe caused by someone or something on account of an unexpected activity or its results. Faced with a deed generating astonishment, the person who sees or experiences it begins to feel respect and admiration. ${ }^{148} \mathrm{An}$ object of this attitude in the Greek version of Sir are the priests (7:29) and the tales of the sailors (43:24). The sage cautions his readers not to admire the deeds of a sinner (11:21). Likewise, one should not be astonished at the transgressions

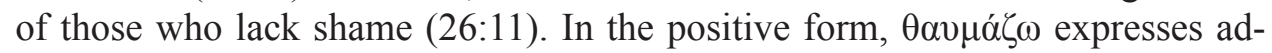

145 See Piwowar, "Uczony w Piśmie," 557-561.

146 Zapff (Jesus Sirach $25-51,254$ ) believes that the doctor enjoys the same dignity as the nobles.

147 See Sauer, Jesus Sirach/Ben Sira, 262.

148 Such a meaning of the verb is emphasized by its etymology: " $\theta \alpha v \mu \alpha ́ \zeta \xi \varepsilon v$ and the underlying $\theta \alpha \tilde{v} \mu \alpha$,

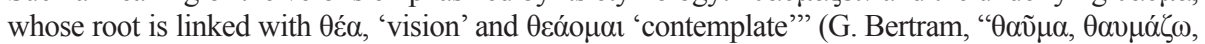

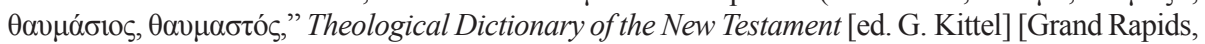
MI: Eerdmans 1995] III, 27). 
miration that at the same time generates respect. It is precisely in this way that the doctor and his work are perceived by the nobles. Like in the case of the king and his gifts bestowed on the physician, the description of the attitude of admiration expressed by the dignitaries towards the knowledge and abilities of the doctor constitutes yet another reason proving the necessity to respect him and show him proper esteem. ${ }^{149}$ Such an approach of the dignitaries is also an indirect encouragement to make use of the doctor's services. The doctor meets with the dignitaries' admiration and respect; if the leaders of the people do that, by the same token all the subjects should not avoid or ignore him. It can be claimed that it is an argument based on the authority of the dignitaries, as was the case with the king (see 38:2b).

The Hebrew version of Sir 38:3 ${ }^{150}$ differs only slightly from its translation into Greek. The original text mentions the fact that the doctor will be present (ניצב - "the Hiphil form of the root present," "to turn up") among the dignitaries (נדיבים), and not that he will be praised by them. ${ }^{151}$ The translation conducted by the sage's grandson emphasized the doctor's fame and the admiration generated by his abilities, while the original text seems to accentuate the fact that the doctor is a member of the royal court, ${ }^{152}$ who serves also the dignitaries. ${ }^{153}$

\section{Conclusion}

In 38:1-3 Sirach calls on all the believing Jews to radically change their attitude to physicians and their work. He appeals to them not to reject the service of doctors, which tendency was characteristic of an earlier biblical tradition. The

149 Cranz ("Advice for a Successful Doctor's Visit," 240-241) claims that the presentation of the doctor in Sir 38:2-3 as a person belonging to the group in positions of power (kings and dignitaries) is caused by Hellenistic influences, even though she concedes that the presence of the physicians on royal courts was a commonplace in the ancient Middle East.

150 The Hebrew text reads as follows: דעת רואפ תרים ראשו ולפני נדיבים יתיצב. Bmarg suggests that נדיבים should be replaced with the word מלכים. Di Lella views the reading suggested by the margin as an influence of Prov 22:29b (see Skehan - Di Lella, The Wisdom of Ben Sira, 441; cf. Middendorp, Die Stellung Jesu Ben Siras, 39, 81, 142, 151; Schrader, "Beruf, Arbeit und Muße," 138, footnote 90).

151 N. Peters sees $\theta \alpha v \mu \alpha \sigma \theta \dot{\sigma} \sigma \varepsilon \tau \alpha$ as a free translation of the Hebrew text (see Peters, Hebräische Text des Buches Ecclesiasticus, 156).

152 See Askin, Scribal Culture in Ben Sira, 195 Fasce, La lode del medico, 32-33; Stöger, "Der Arzt nach Jesus Sirach (38,1-15)", 5.

153 "The Greek ('in the presence of the great he will be wondered at') and Syriac read that the physician has honour in the presence of nobles, but the Hebrew suggests physicians should be honoured because they serve nobles. The Greek is perhaps an interpretation of 'standing before' without the full force of the Hebrew combination צב לפני, which indicates an act of service" (Askin, Scribal Culture in Ben Sira, 196). 
pericope under study here claims the opposite: a doctor should be respected and his services should be sought in times of sickness and suffering. The sage bases this new approach to doctors on two arguments. The first of them may be treated as theological or religious. The doctor was created by God and it is God who heals all the suffering ones from their ailments (38:2a). The doctor is merely an intermediary of God's healing power. This aspect is emphasized more strongly by the Hebrew text than by its translation into Greek. ${ }^{154}$ The second argument stresses the need to show respect to the doctor and it cautions against despising the doctor, as even the rulers and dignitaries do not reject him but show him highest recognition and gratitude for his help in curing their illnesses and restoring their health. It is a social argument, stemming from the authority of those in positions of power. ${ }^{155}$ As far as the second argument is concerned, Ben Sira indirectly shows the doctor as the sage that possesses knowledge, likening him to the scribe when it comes to the position occupied within the social hierarchy. By referring to these two facts (especially the first one), Ben Sira perfectly synthesizes faith and Hellenistic influences pertaining to medicine. ${ }^{156}$ On the one hand, he seems to be open to beneficial influences of the Greek culture that do not threaten the identity of Israel, while on the other he appears as a conservative defender of the faith and tradition of his nation, maintaining God's supreme position in healing and restoring health. Healing comes from him; it is God who heals, while the doctor is a mere intermediary of the Divine Doctor's healing power. ${ }^{157}$ Ben Sira takes note of positive sides of Hellenism that may help the believer, but he endows them with a theological/religious significance and justifies them with God's activity.

154 See Adinolfi, "Il medico in Sir 38,1-15," 177; Cranz, "Advice for a Successful Doctor's Visit," 242-243; Lührmann, "Aber auch Arzt gib Raum (Sir 38,1-15)," 61.

155 See Sulmasy, "The Covenant within the Covenant," 21; Zapff, "Sir 38,1-15 als Beispiel," 358.

156 "Ben Sira, che certo è consapevole dello stacco che si è prodotto fra la mentalità dei pardi e l'inculturazione ellenistica, si muove con naturalezza fra l'antico e il nuovo, non tanto per introdurre il nuovo, quanto per consolidare la tradizione giudaica, entro cui agiscono istanze e correnti culturali di provenienza greco-alessandrina: infatti, la lode del medico parte con l'ossequioso riconoscimento delle sue prestazioni, ma subito si inquadra in una prospettiva religiosa, proclamando che il medico e la sua scienza sono doni della creazione divina" (Fasce, La lode del medico, 31-32). Cf. O. Wischmeyer, Die Kultur des Buches Jesus Sirach (BZNW 277; Berlin - New York: de Gruyter 1995) 47.

157 See J.L. Crenshaw, “The Book of Sirach,” The New Interpreter's Bible (ed. L.E. Keck) (Nashville 1997) V, 807. 


\section{Bibliography}

Adinolfi, M., "Il medico in Sir 38,1-15," Antonianum 62 (1987) 172-183.

Allan, N., "The Physician in Ancient Israel: His Status and Function," Medical History 45 (2001) 377-394.

Alonso Schökel, L., Proverbios y Eclesiastico (Los Libros Sagrados 11; Madrid: Cristiandad 1968).

Askin, L.A., Scribal Culture in Ben Sira (Sir 38:1-15; 41:1-15; 43:11-19; 44-50) (unpublished doctoral dissertation defended in 2016 in Queen's College, Cambridge University).

Beeks, R., Etymological Dictionary of Greek (Leiden Indo-European Etymological Dictionary Series 10; Leiden - Boston, MA: Brill 2010) I-II.

Beentjes, P.C., The Book of Ben Sira in Hebrew. A Text Edition of all Extant Hebrew Manuscripts and a Synopsis of all Parallel Hebrew Ben Sira Texts (Supplements to Vetus Testamentum 68; Leiden - New York - Köln: Brill, 1997).

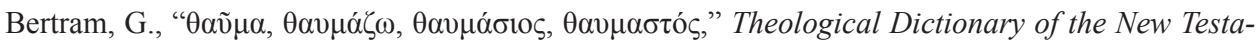
ment (ed. G. Kittel) (Grand Rapids, MI: Eerdmans 1995) III, 27-42.

Boccaccio, P. - Bernardi, G., Ecclesiasticus. Textus hebraeus secundum fragmenta reperta (Roma: PIB 1986).

The Book of Ben Sira. Text, Concordance and an Analysis of the Vocabulary (The Historical Dictionary of the Hebrew Language; Jerusalem: The Academy of the Hebrew Language and the Shrine of the Book 1973).

Box, G.H. - Oesterley, W.O.E., "The Book of Sirach," The Apocrypha and Pseudepigrapha of the Old Testament in English with Introductions and Critical and Explanatory Notes to the Several Books. I. Apocrypha (ed. R.H. Charles) (Oxford: Clarendon Press 1913) 268-517.

Brown, M.L., "רָָָָ rāpā'," Theological Dictionary of the Old Testament (ed. G.J. Botterweck H. Ringgren - H.-J. Fabry) (Grand Rapids, MI - Cambridge: Eerdmans 2004) XIII, 593-602.

Chrostowski, W., "Lekarz i jego posługa w świetle Biblii," Collectanea Theologica 3 (2001) 51-67.

Corley, J., "Respect and Care for Parents in Sirach 3,1-16," Family and Kinship in the Deuterocanonical and Cognate Literature (ed. A. Passaro) (Deuterocanonical and Cognate Literature. Yearbook 2012/2013; Berlin - Boston, MA: De Gruyter 2013) 139-172.

Corley, J., Sirach (New Collegeville Bible Commentary 21; Collegeville, PA: Liturgical Press 2013).

Cranz, I., “Advice for a Successful Doctor's Visit: King Asa Meets Ben Sira," Catholic Biblical Quarterly 80 (2018) 231-246.

Crenshaw, J.L., "The Book of Sirach. Introduction, Commentary, and Reflection," The New Interpreter's Bible (ed. L.E. Keck) (Nashville, TN: Abingdon Press 1997) V, 603-867.

Drawnel, H., The Aramaic Astronomical Book (4Q208-4Q211) from Qumran. Text, Translation, and Commentary (Oxford: Oxford Press 2010).

Duesberg, H., "Le médecin, un sage (Ecclésiastique 38,1-15)," Bible et Vie Chrétienne 38 (1961) 43-48.

Fasce, S., La lode del medico nel libro biblico del Siracide (Genova: ECIG 2009).

Gaiser, F., “"The Sensible Will Not Despise Him': Healing Medicine, Human Wisdom and God (Sirach 38:1-15)", Healing in the Bible: Theological Insight for Christian Ministry (ed. F.J. Gaiser) (Grand Rapids, MI: Baker 2010) 117-131.

Giblet, J. - Grelot, P., “Choroba-uleczenie,” Stownik teologii biblijnej (ed. X. Leon-Dufour) (Poznań: Pallottinum 1990) 121-125. 
Graber, F. - Müller D., “ióoual,” New International Dictionary of the New Testament Theology (ed. C. Brown) (Carlise - Grand Rapids, MI: Paternoster Press 1986) II, 166-169.

Kee, H.C., "Medicine and Healing," The Anchor Bible Dictionary (ed. D.N. Freedman) (New York - London - Toronto: Doubleday 1992) IV, 659-664.

Kraus, W. - Karrer, M. (ed.), Septuaginta Deutsch. Das griechische Alte Testament in deutscher Übersetzung (Stuttgart: Deutsche Bibelgesellschaft 2009).

Księgi greckie. Przekład interlinearny z kodami gramatycznymi i indeksem form podstawowych (trans. M. Wojciechowski) (Prymasowska Seria Biblijna; Warszawa: Vocatio 2008).

Lévi, I., The Hebrew Text of the Book of Ecclesiasticus (Semitic Study Series; Leiden: Brill 1904).

Liesen, J., Full of Praise. An Exegetical Study of Sir 39,12-35 (Supplements to the Journal for the Study of Judaism 64; Leiden - Boston, MA - Köln: Brill 2000).

Liddell, H.G. - Scott, R., A Greek-English Lexicon, 10th ed. (Oxford: Clarendon Press 1996).

Lührmann, D., “Aber auch Arzt gib Raum (Sir 38,1-15)," Wort und Dienst 15 (1979) 55-78.

Marböck, J., Jesus Sirach 1 - 23 (Herders Theologischer Kommentar zum Alten Testament; Freiburg - Basel - Wien: Herder 2010).

Marböck, J., Weisheit im Wandel. Untersuchungen zur Weisheitstheologie bei Ben Sira (BZAW 272; Berlin - New York: de Gruyter 1999).

Mazzinghi, L., “«Poi fa’ posto al Medico, perché ti è necessario» (Sir 38,1-15),” Parola Spirito e Vita 40 (1999) 65-74.

Middendorp, T., Die Stellung Jesu Ben Siras zwischen Judentum und Hellenismus (Leiden: Brill 1973).

Minissale, A., Siracide (Ecclesiastico), 3rd ed. (Nuovissima Versione della Bibbia 23; Cinisello Balsamo: San Paolo 2002).

Minissale, A., Siracide. Le radici nella tradizione (Leggere Oggi la Bibbia 1.17; Brescia: Queriniana 1988).

Montanari, F., Vocabolario della lingua greca, 2nd ed. (Torino: Loescher 2004).

Mopsik, C., La Sagesse de ben Sira (Les Dix Paroles; Paris: Verdier 2003).

Morla, V., Los manuscritos hebreos de Ben Sira. Traducción y notas (Asociación Bíblica Española 59; Estella: Verbo Divino 2012).

Mulder, O., Simon the High Priest in Sirach 50. An Exegetical Study of the Significance of Simon the High Priest as Climax to the Praise of the Fathers in Ben Sira's Concept of the History of Israel (Supplements to the Journal for the Study of Judaism 78; Leiden - Boston, MA: Brill 2003).

Muraoka, T., A Greek-English Lexicon of the Septuagint (Louvain - Paris - Walpole, MA: Peeters 2009).

Münnich, M., Obraz Jahwe jako władcy choroby w Biblii hebrajskiej na tle bóstw bliskowschodnich (Lublin: Wydawnictwo KUL 2004).

Noorda, S., "Illness and Sin, Forgiving and Healing: The Conception of Medieval Treatment and Religious Beliefs in Ben Sira 38,1-15," Studies in Hellenistic Religions (ed. M. Vermaseren) (Études Préliminaires aux Religions Orientales dans L'Empire Romain 78; Leiden: Brill 1979) 215-224.

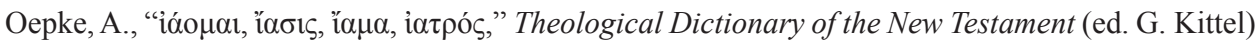
(Grand Rapids, MI: Eerdmans 1995) III, 194-215.

Palmisano, M.C., Siracide. Introduzione, traduzione e commento (Nuova Versione della Bibbia dai Testi Antichi 34; Cinisello Balsamo: San Paolo 2016). 
Pérez Rodríguez, G., "Eclesiástico,” Biblia Comentada. IV. Libros Sapienciales, 2nd ed. (Biblioteca de Autores Cristianos 218; Madrid: Editorial Católica 1967) 1072-1307.

Peters, N., Das Buch Jesus Sirach oder Ecclesiasticus (Exegetisches Handbuch zum Alten Testament 25; Münster: Aschendorff 1913).

Peters, N., Hebräische Text des Buches Ecclesiasticus (Freiburg im Breisgau: Herdersche Verlagschandlung 1902).

Pietersma, A. - Wright, B.G. (ed.), A New English Translation of the Septuagint. And the Other Greek Translations Traditionally Included under that Title (New York - Oxford: Oxford University Press 2007).

Piwowar, A., "Dwie drogi prowadzące do odnalezienia mądrości według Syracha. Analiza egzegetyczno-teologiczna Syr 51,13-30," Biblical Annals 4/1 (2014) 57-96.

Piwowar, A., "Początkowa koncepcja mądrości według Syracha. Syr 1,1-10 jako perykopa programowa," Biblical Annals 4/2 (2014) 397-449.

Piwowar, A., Składnia języka greckiego Nowego Testamentu, 2nd ed. (Materiały Pomocnicze do Wykładów z Biblistyki 13; Lublin: Wydawnictwo KUL 2017).

Piwowar, A. "Uczony w Piśmie - ideał człowieka poszukującego mądrości (Syr 38,24; 39,1-11)," Biblical Annals 6/4 (2016) 527-600.

Piwowar, A., “Wierność w czasie próby (Syr 2,1-6),” Verbum Vitae 11 (2007) 99-126.

Piwowar, A., "Zdobycie mądrości według Syracha (Syr 6,18-37). Część I: Przyjęcie wychowania prowadzi do osiągnięcia mądrości (Syr 6,18-22)," Biblical Annals 1 (2015) 111-135.

von Rad, G., La sapienza in Israele (Genova: Marietti 1998).

Rahlfs, A. (ed.), Septuaginta. Id est Vetus Testamentum graece iuxta LXX interpretes I-II (Stuttgart: Deutsche Bibelgesellschaft, 1979) I-II.

Ravasi, G., "Malattia, Guarigione e medici nell'Antico Testamento," Parola, Sprito e Vita 40 (1999) 11-22.

Reiterer, F.V., “Alle Weisheit stammt vom Herrn...”. Gesammelte Studien zu Ben Sira (BZAW 375; Berlin - New York: de Gruyter 2007).

Romizi, R., Greco antico. Vocabolario greco italiano etimologico e ragionato, 3rd ed. (Bologna: Zanichelli 2007).

Rykel, L. - Wilhoit, J.C. - Longman III, T. (ed.), Le immagini bibliche. Simboli, figure retoriche e temi letterari della Bibbia (Dizionari San Paolo; Cinisello Balsamo: San Paolo 2006).

Sauer, G., Jesus Sirach/Ben Sira (Das Alte Testament Deutsch. Apokryphen 1; Göttingen: Vandenhoeck \& Ruprecht 2000).

Schrader, L., "Beruf, Arbeit und Muße als Sinnerfüllung bei Jesus Sirach," Der Einzelne und seine Gemeinschaft bei Ben Sira (ed. R. Egger-Wenzel - I. Krammer) (BZAW 270; Berlin - New York: de Gruyter 1998) 117-149.

Schreiner, J., Jesus Sirach 1 - 24 (Die Neue Echter Bibel. Altes Testament; Würzburg: Echter 2002).

Septuaginta czyli Biblia Starego Testamentu wraz z księgami deuterokanonicznymi i apokryfami (trans. R. Popowski) (Prymasowska Seria Biblijna; Warszawa: Vocatio 2013).

Skehan, P.W. - Di Lella, A.A., The Wisdom of Ben Sira (The Anchor Bible 39; New York - London - Toronto: Doubleday 1987).

Smend, R., Die Weisheit des Jesus Sirach erklärt (Berlin: Reimer 1906).

Smend, R., Die Weisheit des Jesus Sirach hebräisch und deutsch (Berlin: Reimer 1906). 
Snaith, J.G., Ecclesiasticus or The Wisdom of Jesus Son of Sirach (The Cambridge Bible Commentary; Cambridge: Cambridge University Press 1974).

Stabryła, W.M., “Najlepszego nawet lekarza czeka Gehenna'. Lekarz w starożytnym Izraelu,” Ateneum Kapłańskie 1 (2013) 7-13.

Stabryła, W.M., "Zdrowie i choroba w starożytnym Izraelu," Więcej szczęścia jest $w$ dawaniu aniżeli w braniu. Księga Pamiątkowa dla Księdza Profesora Waldemara Chrostowskiego w 60. rocznice urodzin (ed. B. Strzałkowska) (Ad Multos Annos; Warszawa: Adam 2011) III, 1313-1334.

Stöger, A., "Der Arzt nach Jesus Sirach (38,1-15)," Arzt und Christ 1/11 (1965) 3-11.

Sulmasy, D.P., "The Covenant within the Covenant: Doctors and Patients in Sir 38:1-15," Linacre Quaorterly 55 (1988) 14-24.

Testa, E., "Le malattie e il medico secodno la Bibbia," Rivista Biblica 43 (1995) 253-267.

Turkiel, J., "Septuaginta o lekarzu," Nauki humanistyczne i sozologia. Księga jubileuszowa dedykowana Księdzu Profesorowi zwyczajnemu doktorowi habilitowanemu Józefowi M. Dołędze (ed. J.W. Czartoszewski) (Warszawa: Wydawnictwo UKSW 2010) 563-570.

Vella, J., "Eclesiastico," La Sagrada Escritura. Texto y comentario. Antiguo Testamento. V. Eclesiástico, Isaía, Jeremías, Ezequiel (ed. A.T. Fernández) (Madrid: Editorial Católica 1970) 3-218.

Wischmeyer, O., Die Kultur des Buches Jesus Sirach (BZNW 277; Berlin - New York: de Gruyter 1995).

Wolff, H.W., Antropologia dell'Antico Testamento, 4th ed. (Biblioteca Biblica 12; Brescia: Queriniana 2002).

Zakrzewska, M., “Choroba - zło dotykające człowieka,” Biblia a medycyna (ed. B. Pawlaczyk) (Poznań: Księgarnia Świętego Wojciecha 2007) 15-27.

Zapff, B.M., Jesus Sirach 25 - 51 (Die Neue Echter Bibel. Altes Testament: Würzburg: Echter 2010).

Zapff, B.M., "Sir 38,1-15 als Beispiel der Verknüpfung von Tradition und Innovation bei Jesus Sirach," Biblica 92 (2011) 347-367.

Ziegler J., Sapientia Iesu Filii Sirach, 2nd ed. (Septuaginta. Vetus Testamentum Graecum Auctoritate Academiae Scientiarum Gotteingensis editum 12/2; Göttingen: Vandenhoeck \& Ruprecht 1980). http://bensira.org/navigator.php?Manuscript=B\&PageNum=27 [accessed on 8 July 2018] 